B O N N E V I L L E P O W E R A D M I N I S T R A T I O Bull Trout Distribution and Abundance in the Waters on and Bordering the Warm Springs Reservation

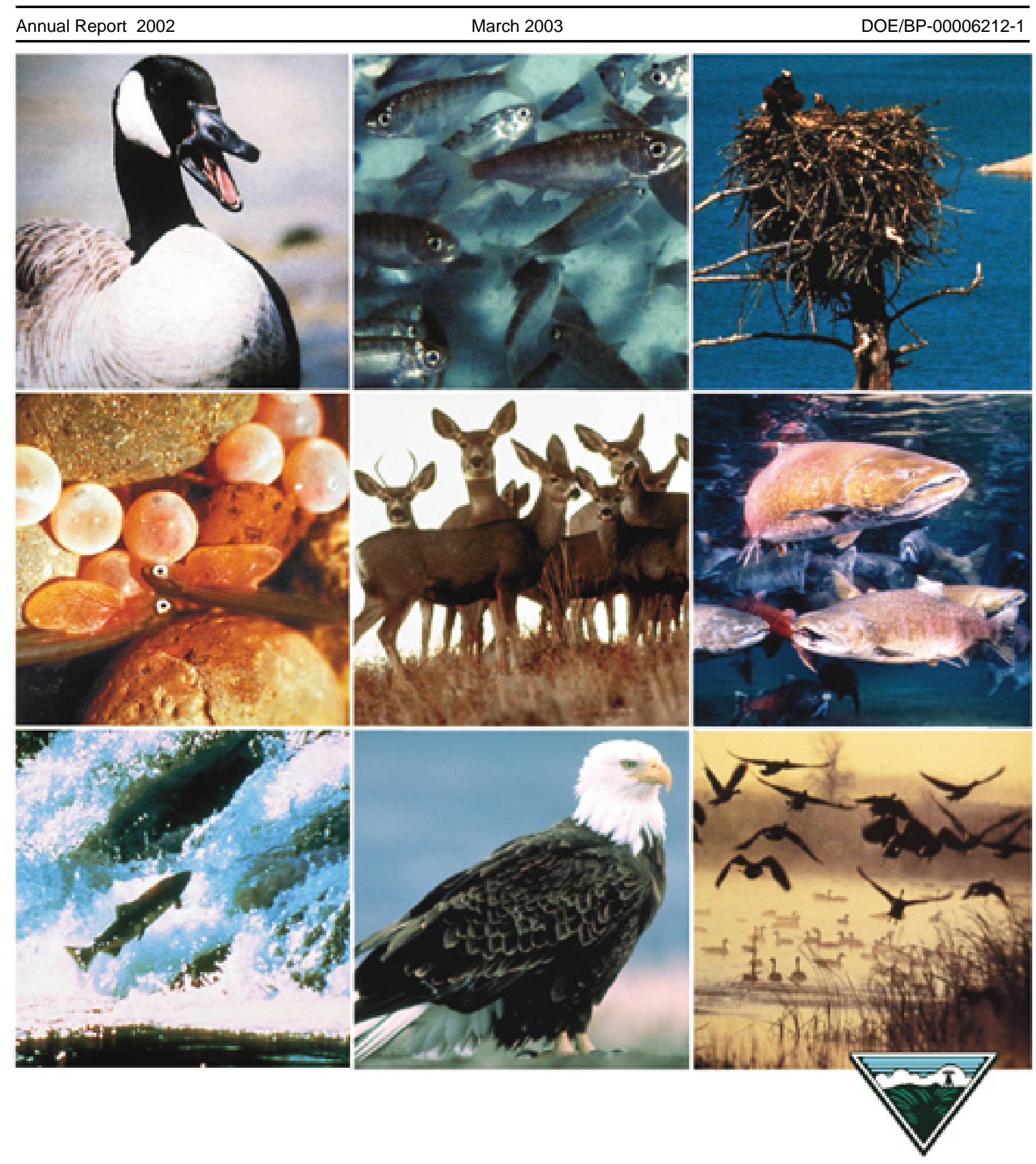


This Document should be cited as follows:

Brun, Christopher, Rebekah Dodson, "Bull Trout Distribution and Abundance in the Waters on and Bordering the Warm Springs Reservation", 2002 Annual Report, Project No. 199405400, 40 electronic pages, (BPA Report DOE/BP-00006212-1)

\author{
Bonneville Power Administration \\ P.O. Box 3621 \\ Portland, OR 97208
}

This report was funded by the Bonneville Power Administration (BPA), U.S. Department of Energy, as part of BPA's program to protect, mitigate, and enhance fish and wildlife affected by the development and operation of hydroelectric facilities on the Columbia River and its tributaries. The views in this report are the author's and do not necessarily represent the views of BPA. 


\title{
BULL TROUT DISTRIBUTION AND ABUNDANCE IN THE WATERS ON AND BORDERING THE WARM SPRINGS RESERVATION
}

\section{ANNUAL REPORT}

\author{
Prepared by: \\ Christopher V. Brun \\ Rebekah R. Dodson \\ Department of Natural Resources \\ Confederated Tribes of the Warm Springs Reservation, Oregon
}

\author{
Prepared for: \\ U.S. Department of Energy \\ Bonneville Power Administration \\ Environment, Fish and Wildlife \\ P.O. Box 3621 \\ Portland, Oregon, 97208-3621 \\ Project Number 1994-054 \\ Contract Number 479 Amendment 05
}




\begin{abstract}
The range of bull trout (Salvelinus confluentus) in the Deschutes River basin has decreased from historic levels due to many factors including dam construction, habitat degradation, brook trout introduction and eradication efforts. While the bull trout population appears to be healthy in the Metolius River-Lake Billy Chinook system they have been largely extirpated from the upper Deschutes River (Buchanan et al. 1997). Little was known about bull trout in the lower Deschutes basin until BPA funded project \#9405400 began during 1998. In this progress report we describe the findings to date from this multi-year study aimed at determining the life history, habitat needs and limiting factors of bull trout in the lower Deschutes subbasin.
\end{abstract}

Juvenile bull trout and brook trout (Salvelinus fontinalis) relative abundance has been assessed in the Warm Springs River and Shitike Creek since 1999. In the Warm Springs $\mathrm{R}$. the relative densities of juvenile bull trout and brook trout were $.003 \mathrm{fish} / \mathrm{m}^{2}$ and .001 fish $/ \mathrm{m}^{2}$ respectively during 2002. These densities were the lowest recorded in the Warm Springs River during the period of study. In Shitike Cr. the relative densities of juvenile bull trout and brook trout were $.025 \mathrm{fish} / \mathrm{m}^{2}$ and $.01 \mathrm{fish} / \mathrm{m}^{2}$ respectively during 2002 .

The utility of using index reaches to monitor trends in juvenile bull trout and brook trout relative abundance in the Warm Springs R. has been assessed since 1999. During 2002 the mean relative densities of juvenile bull trout within the $2.4 \mathrm{~km}$ study area was higher than what was observed in four index reaches. However, the mean relative densities of brook trout was slightly higher in the index reaches than what was observed in the $2.4 \mathrm{~km}$ study area.

Habitat use by both juvenile bull trout and brook trout was determined in the Warm Springs R. Juvenile bull trout and brook trout were most abundant in pools and glides. However pools and glides comprised less than $20 \%$ of the available habitat in the study area during 2002.

Multiple-pass spawning ground surveys were conducted during late August through October in the Warm Springs R. and Shitike Cr. during 2002. One-hundred and thirteen (113) redds were enumerated in the Warm Springs R. and 204 redds were found in Shitike Cr. The number of redds enumerated in both the Warm Springs R. and Shitike Cr. were the most redds observed since surveys began in 1998. Spatial and temporal distribution in spawning within the Warm Springs R. and Shitike Cr. is discussed.

Juvenile emigration has been monitored in Shitike Creek since 1996. A total of 312 juveniles were estimated to have emigrated from Shitike Cr. during the spring, 2002. Adult escapement was monitored in the Warm Springs R. and Shitike Cr. Thirty adults were recorded at the Warm Springs National Fish Hatchery weir during 2002. This was the highest number of spawning adults recorded to date. A weir equipped with an underwater video camera near the spawning grounds was operated in the Warm Springs R. Thirty-one adults were recorded at the weir in day counts. The adult trap in Shitike 
Cr. was unsuccessful in capturing adult bull trout during 2002 due to damage from a spring high water event.

Thermographs were placed throughout Warm Springs R. and Shitike Cr. to monitor water temperatures during bull trout migration, holding and spawning/rearing periods. During 1999-2002 water temperatures ranged from $11.8-15.4^{\circ} \mathrm{C}$ near the mouths during adult migration; $11.4-14.6^{\circ} \mathrm{C}$ during pre-spawning holding; and $6.5-8.4^{\circ} \mathrm{C}$ during adult spawning and juvenile rearing. 


\section{Table of Contents}

Project Area 5

SECTION I: JUVENILE BULL TROUT AND BROOK TROUT RELATIVE DENSITY MONITORING

Introduction 5

Methods 6

Results and Discussion 7

SECTION II: BULL TROUT SPAWNING SURVEYS

Introduction 15

Methods 15

Results and Discussion 16

SECTION III: JUVENILE AND ADULT BULL TROUT MIGRANT MONITORING Introduction 21

Methods__ 22

Results and Discussion__ 23

SECTION IV: WATER TEMPERATURE MONITORING IN BULL TROUT HABITAT IN WARM SPRINGS RIVER AND SHITIKE CREEK

Introduction 27

Methods 27

Results and Discussion 28

REFERENCES 33

APPENDIX A: Juvenile Bull Trout Survey Locations 36 APPENDIX B: Warm Springs River Index Reach Locations 37 APPENDIX C: Bull Trout Spawning Survey Index Reaches 38 


\section{Project Area}

The Warm Springs Reservation covers 240,000 hectares. It is located on the eastern slopes of the Cascade Mountains in central Oregon. The Reservation boundaries run from the crest of the Cascades to the north and west, the Deschutes River to the east and the Metolius River to the south. The Warm Springs River and Shitike Creek, major tributaries to the lower Deschutes River, are located within the Reservation. The lower Deschutes River flows below an impassable hydroelectric complex at river kilometer (Rkm) 161. The Pelton - Round Butte complex has isolated bull trout populations in the Metolius River from those in the lower Deschutes River since the 1960's.

The project was conducted in two Reservation watersheds: Warm Springs and Shitike. The Warm Springs River is the largest river system within the Reservation. The river flows for 85 kilometers and drains 54,394 hectares. Major tributaries include Beaver Creek and Mill Creek. It is the largest tributary to the lower Deschutes River. It enters the Deschutes at Rkm 135. Shitike Creek is the third largest tributary to the lower Deschutes River. It flows for $48 \mathrm{~km}$ and drains 36,000 hectares. Shitike Creek enters the Deschutes River at Rkm 151.

\section{Section I \\ Juvenile Bull Trout Relative Abundance Monitoring}

\section{Introduction}

Bull trout require complex stream habitat and cold-water temperatures $\left(<15^{\circ} \mathrm{C}\right)$ during the juvenile life stage (Dambacher and Jones 1997; Fraley and Shepard 1989; Ratliff 1992; Reiman and McIntyre 1992). Such habitat is limited to the headwaters of many streams within the Pacific Northwest. Juveniles rear in streams from two to three years or longer (Ratliff et al. 1996; Pratt 1992). Historic land management activities, including timber harvest and livestock grazing, have reduced the quality and quantity of naturally limited rearing habitat throughout the range of the bull trout (Fraley and Shepard 1989).

The presence of non-native brook trout (Salvelinus fontinalis) in juvenile bull trout habitat may pose a serious threat to bull trout from hybridization and competition (Ratliff and Howell 1992). Brook trout are present throughout all of the known juvenile bull trout rearing habitat in the Warm Springs River and a portion of Shitike Creek (Brun 1999).

Monitoring the abundance and distribution of juvenile bull trout within a stream is essential to assess the health of a given population. However, due to limited resources and access difficulties, many bull trout population are monitored by sub-sampling portions of juvenile rearing habitat. It is unknown how representative these "index" reaches are to the whole juvenile population in many streams. In the Warm Springs River juvenile bull trout distribution is confined to a $3.6 \mathrm{~km}$ portion of the stream. Access is good to the majority of juvenile rearing habitat. These circumstances provide an opportunity to assess the utility of using "index" reaches to assess the trends in 
juvenile bull trout and sympatric brook trout relative abundance in the majority of juvenile rearing habitat within the Warm Springs River.

Beginning in 1999, the relative densities of juvenile bull trout and sympatric brook trout were assessed in the Warm Springs River and Shitike Creek. Within the Warm Springs River the objectives were to:

1.) Determine relative densities of juvenile bull trout and brook trout in the study Area.

2.) Determine habitat unit use by both species.

3.) Collect data to assess the utility of using "index" reaches for monitoring trends in juvenile bull trout and brook trout relative abundance by comparing night snorkel total counts in a $2.4 \mathrm{~km}$ reach of the Warm Springs River to 4 "index" reaches

In Shitike Creek, the objective was to monitor trends in juvenile bull trout and brook trout relative abundance by sub-sampling a portion of the available juvenile rearing habitat.

\section{Methods}

\section{Warm Springs River}

\section{$\underline{\text { Habitat Description }}$}

The Oregon Department of Fish and Wildlife (ODFW) Aquatic Inventory Protocol (Moore et al. 1993) was used to classify physical habitat in the study area within the Warm Springs River. Majority habitat features including pools, glides, riffles and rapids were identified. The length and average bankful width of each habitat unit was measured prior to fish enumeration. The surface area $\left(\mathrm{m}^{2}\right)$ of each habitat unit was calculated by multiplying its length by the average bankful width within each unit. The upper and lower bounds of each unit was sequentially numbered with flagging.

"Index" Reaches

Four "index" reaches were established within the study area during initial juvenile bull trout distribution surveys conducted during 1998 (Brun 1999). The "index" reaches ranged from 94-105 $\mathrm{m}$ in length. Each reach began and ended at the beginning of a habitat unit. Prior to fish enumeration the surface area $\left(\mathrm{m}^{2}\right)$ of each index reach was determined using the methods described above. Flagging was placed at both ends of the reach so divers could easily determine the up and downstream bounds. The "index" reaches, when combined, represent approximately $17 \%$ of the total survey area.

\section{$\underline{\text { Juvenile Bull and Brook Trout Enumeration }}$}

Fish enumeration was conducted by night snorkeling using techniques described by Thurow (1994). Juvenile bull trout are nocturnal and readily observable at night. In 
darkness they emerge from concealment and cover such as log jams and substrate interstices (Goetz 1991). Surveys were replicated during the same time period as in previous years (mid-June through early August from 22:00-03:00). Surveys began at the downstream end of the study area (Rkm 56.9) and proceeded upstream to Rkm 59.3. Two or three divers searched each habitat unit for juvenile bull trout and brook trout. The estimated total length of each bull trout and brook trout encountered was recorded. At the end of each habitat unit and "index" reach, the fish counts from each diver were consolidated and recorded.

Bull and brook trout were grouped into one of three length categories (50-200 mm., 200$300 \mathrm{~mm}$. and $>300 \mathrm{~mm}$ total length). These lengths correspond to juvenile (ages I and II), sub-adult (ages III and IV) and adult (IV+) bull trout life stages determined by scale analysis. Age 0 fish were tallied when observed but were not included in the relative density estimates due to difficulty in enumerating this age class by night snorkeling (Goetz 1991)

\section{Shitike Creek}

In Shitike Creek eight index reaches, established during 1998, were re-surveyed during 1999-2001 (refer to Appendix A)[Brun 1999; Brun and Dodson 2000, 2001]. The reaches were randomly located within $1 \mathrm{~km}$ intervals between Rkm 35.8-48.6. A total of $1.1 \mathrm{~km}$ was surveyed (9\% of available juvenile rearing habitat). Survey reaches ranged in length from 109-213 meters. Each reach began and ended at the beginning of a habitat unit. Prior to fish enumeration, the surface area $\left(\mathrm{m}^{2}\right)$ was determined using methods described above. Flagging was placed at both ends of each reach so divers could easily determine the up and downstream reach boundaries. Juvenile bull trout and brook trout were enumerated by night snorkeling according to methods described above.

\section{Results and Discussion}

\section{Warm Springs River}

\section{$\underline{\text { Relative Abundance }}$}

In the Warm Springs R., two-thirds of the known juvenile bull trout distribution $(2.4 \mathrm{~km})$ was surveyed (refer to Appendix A). A total of 86 juvenile bull trout and 35 brook trout were counted between $\mathrm{Rkm}$ 56.9-59.3 during 2002. The relative densities for the entire survey reach were 0.003 juvenile bull trout $/ \mathrm{m}^{2}$ and 0.001 brook trout $/ \mathrm{m}^{2}$. Figure I. 1 displays the relative densities of juvenile bull trout and brook in the $2.4 \mathrm{~km}$ survey reach from 1999-2002. During 2002, juvenile bull trout and brook trout relative densities were the lowest since surveys began in 1999. The estimated densities probably underrepresent the true number of fish present in the study area. This may be due to the presence of complex habitat, such as log jams, deeply undercut banks and numerous small un-surveyed side channels that may have allowed some fish to escape detection. We are in the process of determining the sampling efficiency of night snorkeling 
compared to day snorkeling and electrofishing using the sampling efficiency protocol developed by Thurow and Schill, 1996.

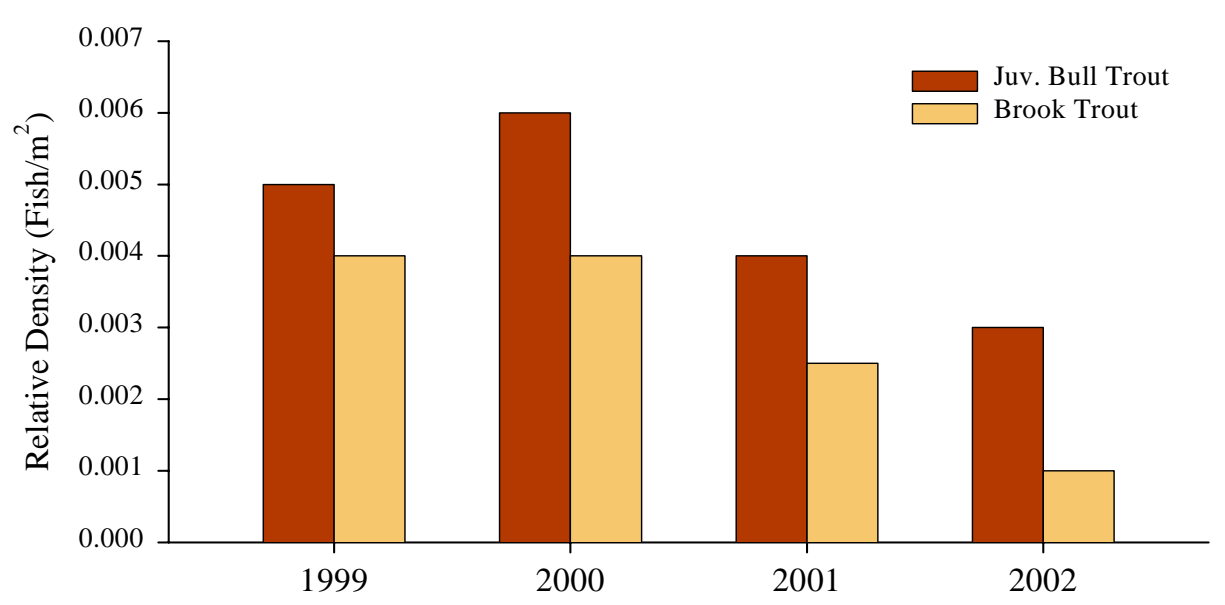

Figure I.1. Relative density of juvenile bull trout and brook trout in the $2.4 \mathrm{~km}$ study area in the Warm Spring R., 1999-2002.

\section{$\underline{\text { Habitat Use }}$}

Pools and glides were the preferred habitat for both juvenile bull trout and brook trout (Figure I.2) within the study area. However, pools and glides accounted for $12.9 \%$ of the total habitat in the study area during 2002. This suggests that preferred juvenile rearing habitat is limited and there may be competition for space within pools and glides between juvenile bull trout and brook trout in the Warm Springs River.

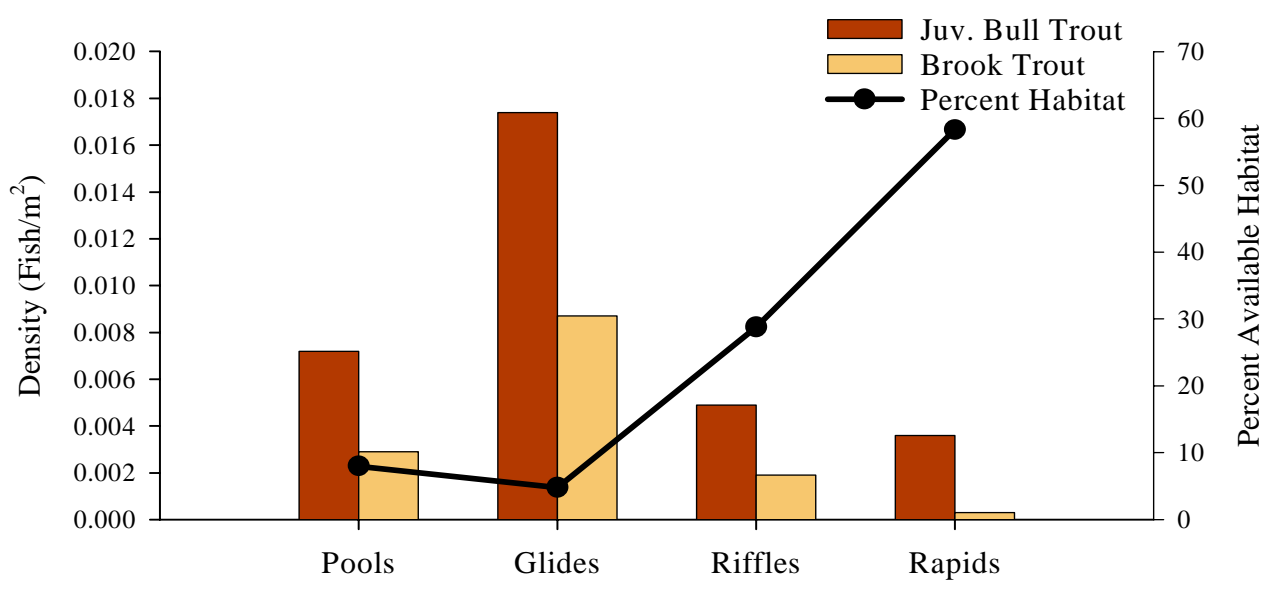

Figure I.2. Juvenile bull trout and brook trout relative densities by habitat type and percentage of each habitat type in the Warm Springs R. 
Pool and glide habitat has been decreasing since 1999 (habitat measurements were not recorded during 2000). During 1999 pools and glides accounted for $19.3 \%$ of total habitat within the $2.4 \mathrm{~km}$ reach. This decreased to $16 \%$ in 2001 and $12.9 \%$ in 2002. With a decrease in area of glides, there was a significant increase in the relative abundance of bull trout in this particular habitat, $.0174 \mathrm{fish} / \mathrm{m}^{2}$ in 2002 compared with $.0055 \mathrm{fish} / \mathrm{m}^{2}$ in 2001 (Figure I.3). During 2002 with a decrease in pool habitat, there was also a decrease in the density of juvenile bull trout in pools, $.0072 \mathrm{fish} / \mathrm{m}^{2}$ in 2002 and $.0144 \mathrm{fish} / \mathrm{m}^{2}$ in 2001 .

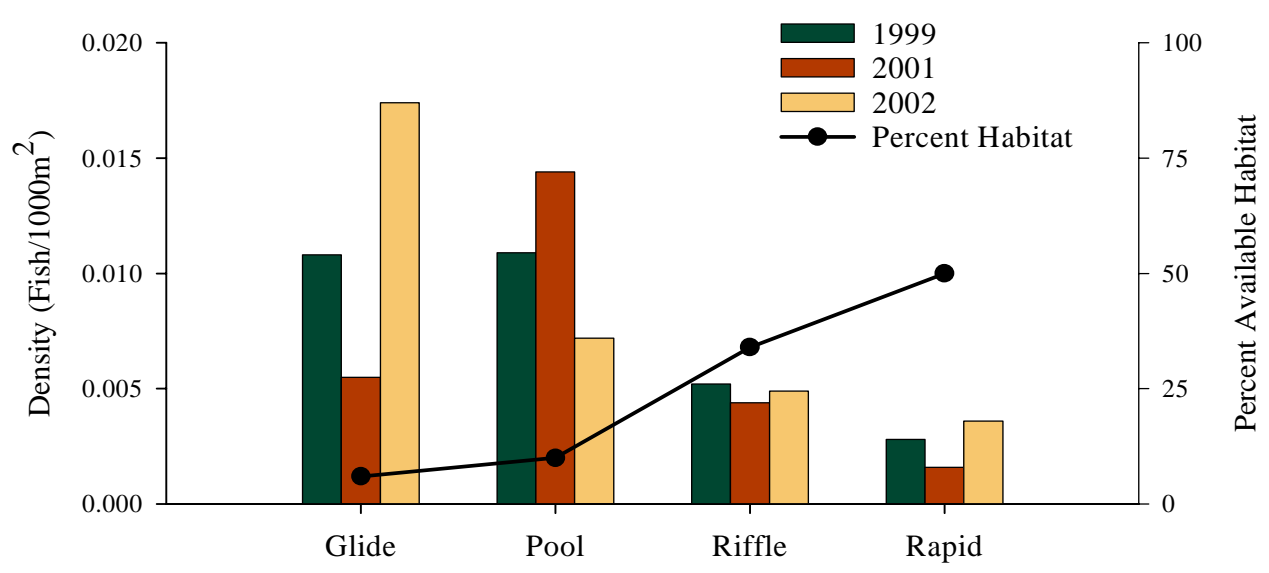

Figure I.3. Comparison of juvenile bull trout relative abundance and the average percent available habitat, 1999,2001 \& 2002.

Brook trout relative abundance in the four habitat types was similar to what was observed with juvenile bull trout. With a decrease in both pools and glides, there was a decrease in relative abundance in pools, $.0088 \mathrm{fish} / \mathrm{m}^{2}$ during 1999 to $.0029 \mathrm{fish} / \mathrm{m}^{2}$ during 2002, and an increase in the relative abundance in glides, $.0044 \mathrm{fish} / \mathrm{m}^{2}$ during 2001 to .0087 fish $/ \mathrm{m}^{2}$ during 2002 (Figure I.4).

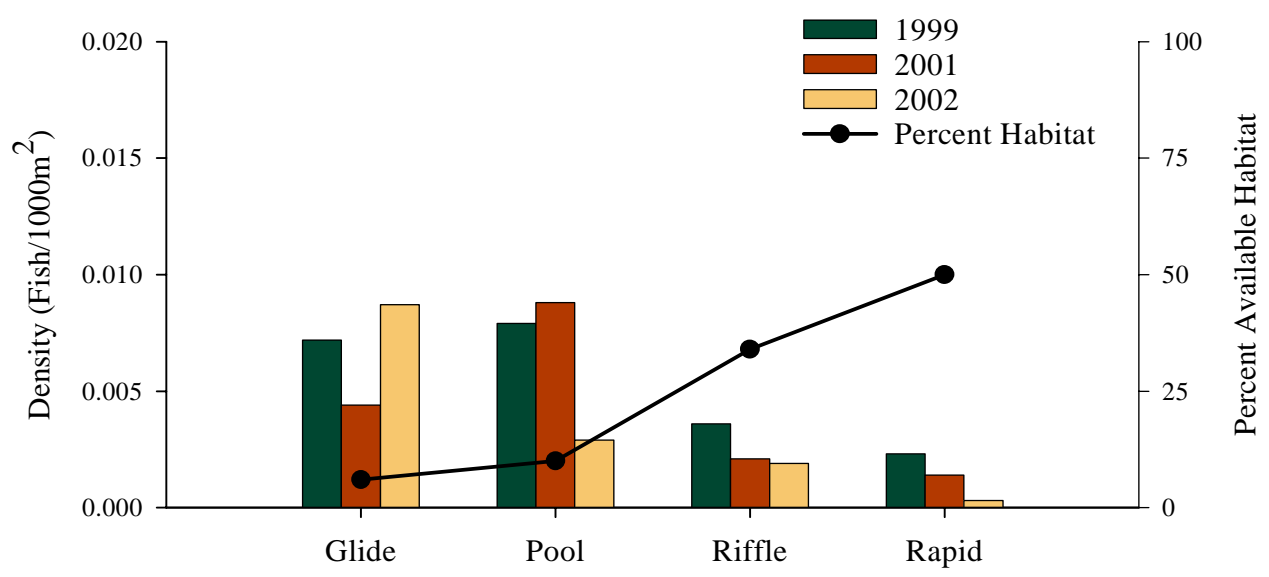

Figure I.4. Comparison of brook trout relative abundance and the average percent available habitat, 1999,2001 \& 2002. 


\section{$\underline{\text { Index Reach Comparison }}$}

As in previous years there was considerable variance in the relative densities of juvenile bull trout and brook trout among the individual index reaches (refer to Appendix B) [Table I.1 and I.2]. The densities observed in three of the four index reaches were significantly different from the density in the study area (Figure I.5). They either underestimated or overestimated the actual density in the study area. However the densities of juvenile bull within reach II was similar to the densities observed within the study area during three of the four years.

Table I.1. Summary statistics for juvenile bull trout relative densities observed within individual index reaches in the Warm Springs River, 1999-2001.

\begin{tabular}{|c|c|c|c|c|c|c|c|c|}
\hline & \multicolumn{4}{|c|}{$\begin{array}{l}\text { Fish } / \mathrm{m}^{2} \text { in Individual Index } \\
\text { Reaches }\end{array}$} & \multirow{2}{*}{$\begin{array}{c}\text { Fish } / \mathrm{m}^{2} \\
\text { Total Survey } \\
\text { Area }\end{array}$} & \multicolumn{3}{|c|}{$\begin{array}{c}\text { Summary Statistics for Index } \\
\text { Reaches }\end{array}$} \\
\hline & 12 & 13 & 14 & 15 & & Mean & Var. & SD. \\
\hline 1999 & .006 & .007 & .003 & .013 & .005 & .007 & .000018 & .0042 \\
\hline 2000 & .011 & .012 & .005 & .013 & .006 & .010 & .000013 & .0036 \\
\hline 2001 & .009 & .005 & .002 & .011 & .004 & .007 & .000016 & .0040 \\
\hline 2002 & .005 & .001 & .002 & .002 & .003 & .0024 & .0000026 & .0016 \\
\hline
\end{tabular}

Table I.2. Summary statistics for brook trout relative densities observed within individual index reaches in the Warm Springs River, 1999-2001.

\begin{tabular}{|c|c|c|c|c|c|c|c|c|}
\hline & \multicolumn{4}{|c|}{$\begin{array}{l}\text { Fish/m } \mathbf{m}^{2} \text { in Individual Index } \\
\text { Reaches }\end{array}$} & \multirow{2}{*}{$\begin{array}{c}\text { Fish } / \mathbf{m}^{2} \\
\text { Total Survey } \\
\text { Area }\end{array}$} & \multicolumn{3}{|c|}{$\begin{array}{c}\text { Summary Statistics for Index } \\
\text { Reaches }\end{array}$} \\
\hline & 12 & 13 & 14 & 15 & & Mean & Var. & SD. \\
\hline 1999 & .003 & .003 & .008 & .005 & .004 & .0045 & .000007 & .0026 \\
\hline 2000 & .012 & 0 & .007 & .004 & .004 & .0058 & .000026 & .0051 \\
\hline 2001 & .0015 & 0 & .002 & .005 & .0025 & .0068 & .000016 & .0040 \\
\hline 2002 & .003 & 0 & 0 & .002 & .0014 & .0013 & .0000023 & .0015 \\
\hline
\end{tabular}

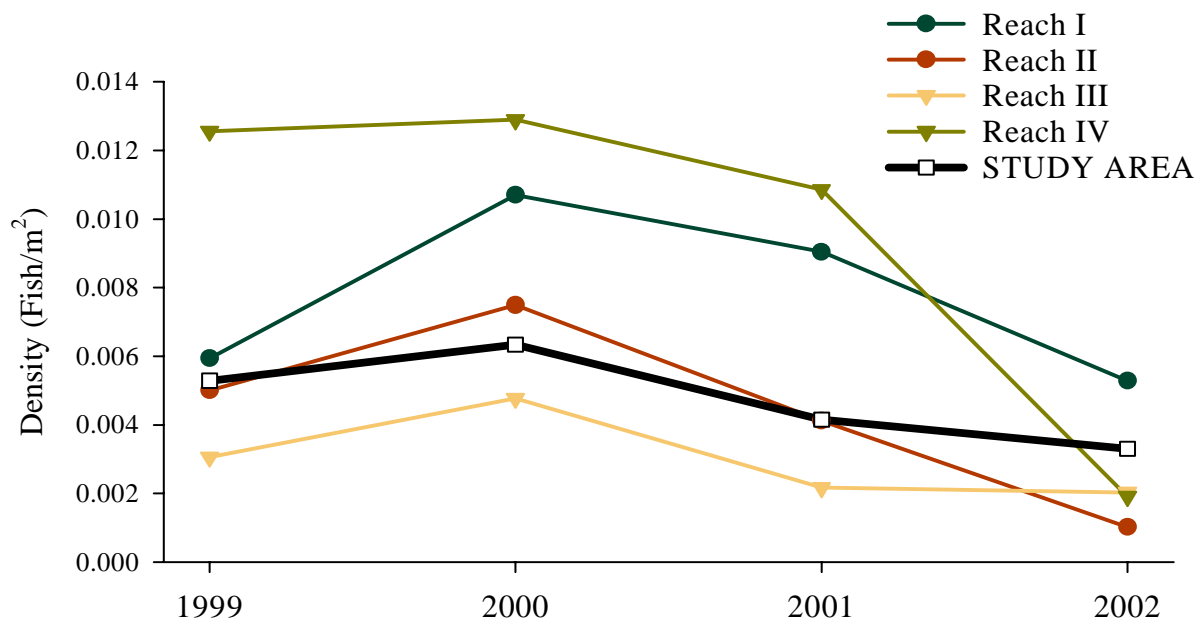

Figure I.5. Relative densities of juvenile bull trout in the individual index reaches and the study area, 2002. 


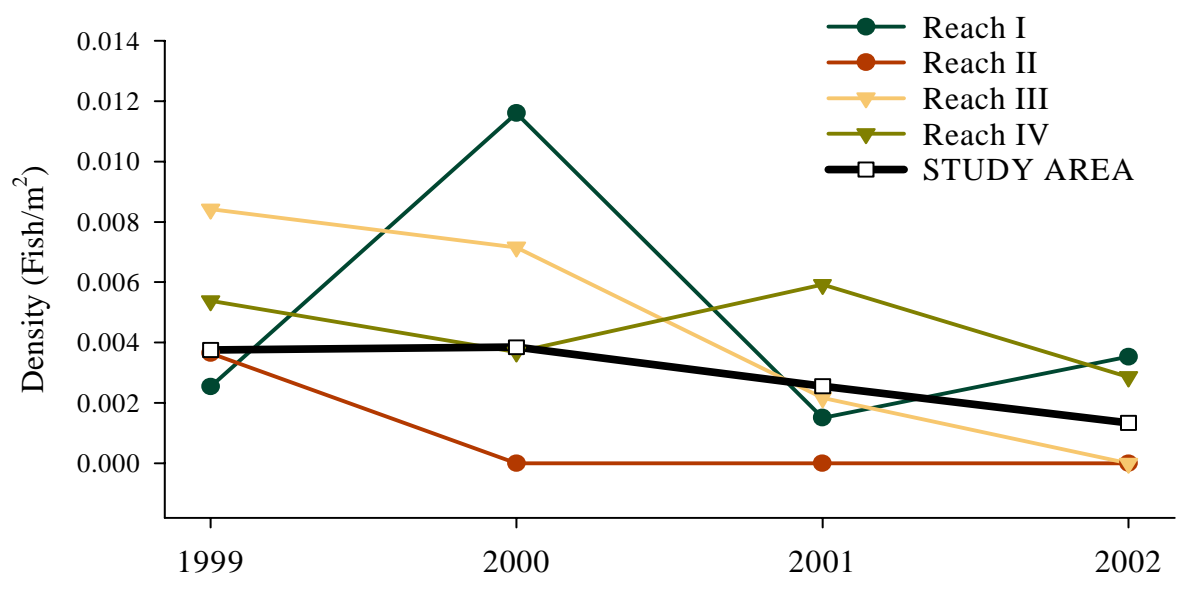

Figure I.6. Relative densities of brook trout in the individual index reaches and the study area, 2002.

Due to the high variances among the densities of the individual index reaches, we chose to combine the four index reaches to determine if sub-sampling a larger area would provide a more representative density estimate. By combining the four index reaches the survey was increased to $17 \%$ of the study area. Unlike previous years, the mean relative density from the combined index reaches was similar to the density of juvenile bull trout and brook trout in the study area during 2002 (Figure I.7 and I.8). From 1999-2001 the mean relative densities within the four combined index reaches has been greater than the relative densities observed within the $2.4 \mathrm{~km}$ study area. However during 2002, the density of the study area was slightly greater than the density in the combined index reaches for juvenile bull trout (Figure I.7). The relative density for brook trout has been similar between the index reaches and the study area over the four years (Figure I.8).

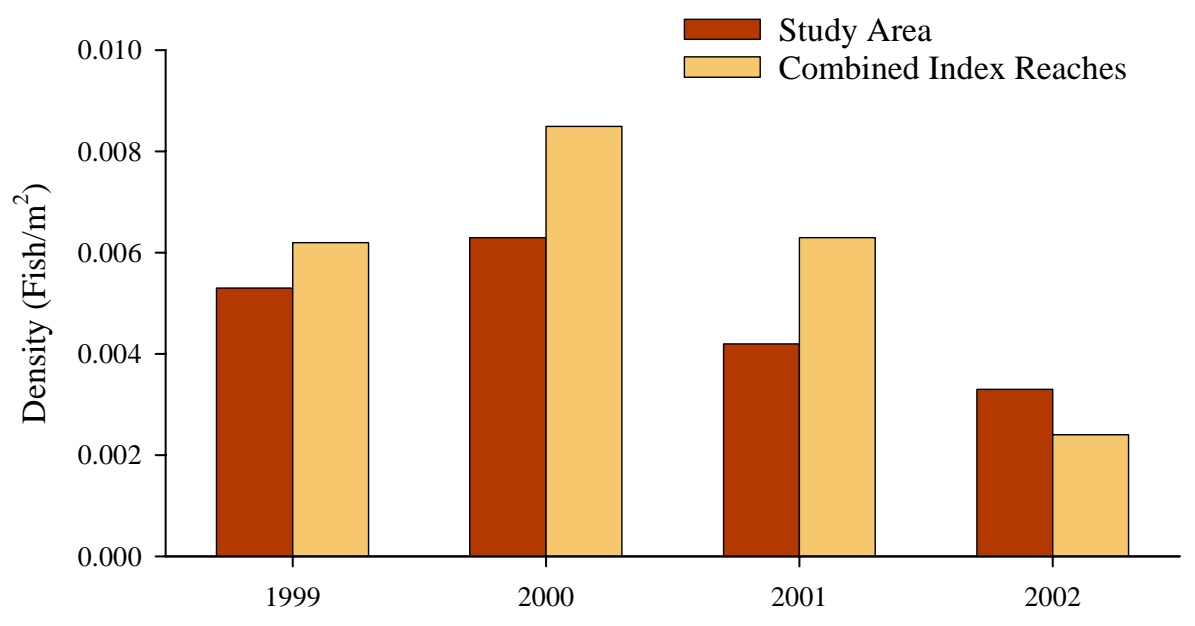

Figure I.7. Relative density of juvenile bull trout within the study area and the combined index reaches in the Warm Springs R., 1999-2002. 


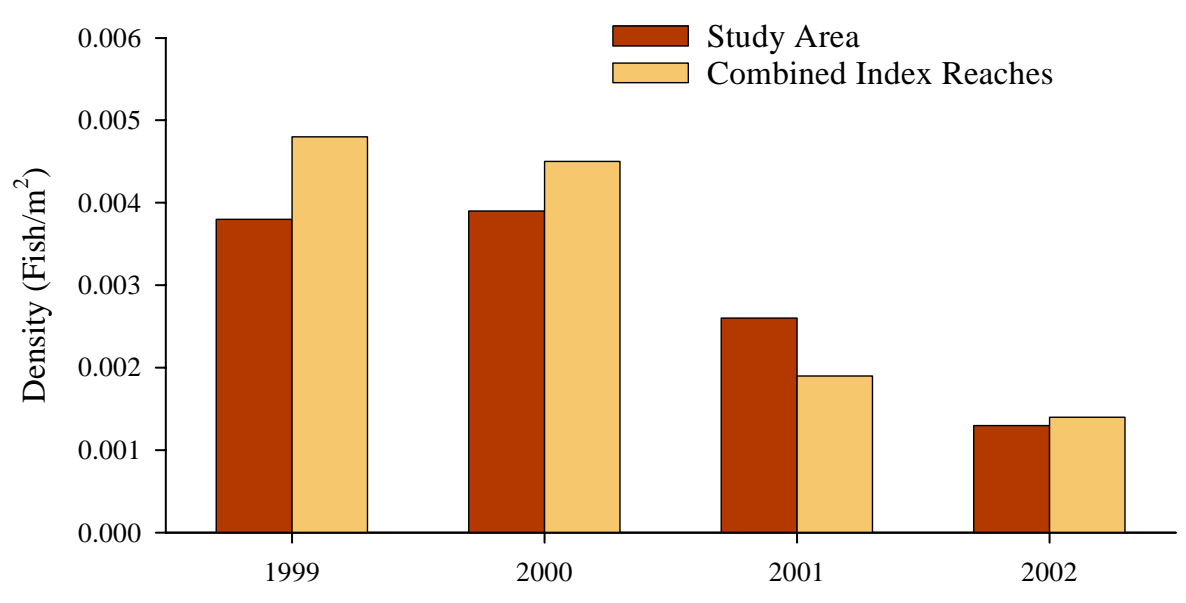

Figure I.8. Relative density of brook trout within the study area and the combined index reaches in the Warm Springs R., 1999-2002.

A regression analysis was conducted to see if there was a correlation between the densities of the combined index reaches and the study area for both juvenile bull trout and brook trout. The correlation between the density of the index reaches and the study area was strong for juvenile bull trout $\left(\mathrm{R}^{2}=.71\right)$ and stronger for brook trout $\left(\mathrm{R}^{2}=.93\right)$ (Figure I.9 and I.10). Despite the relatively short duration of this study it appears that the combined index reaches may be acceptably representative of the relative densities of both juvenile bull trout and brook trout within the Warm Springs River. Additional years of data will determine the significance of these preliminary findings. Surveys will be conducted through 2005.

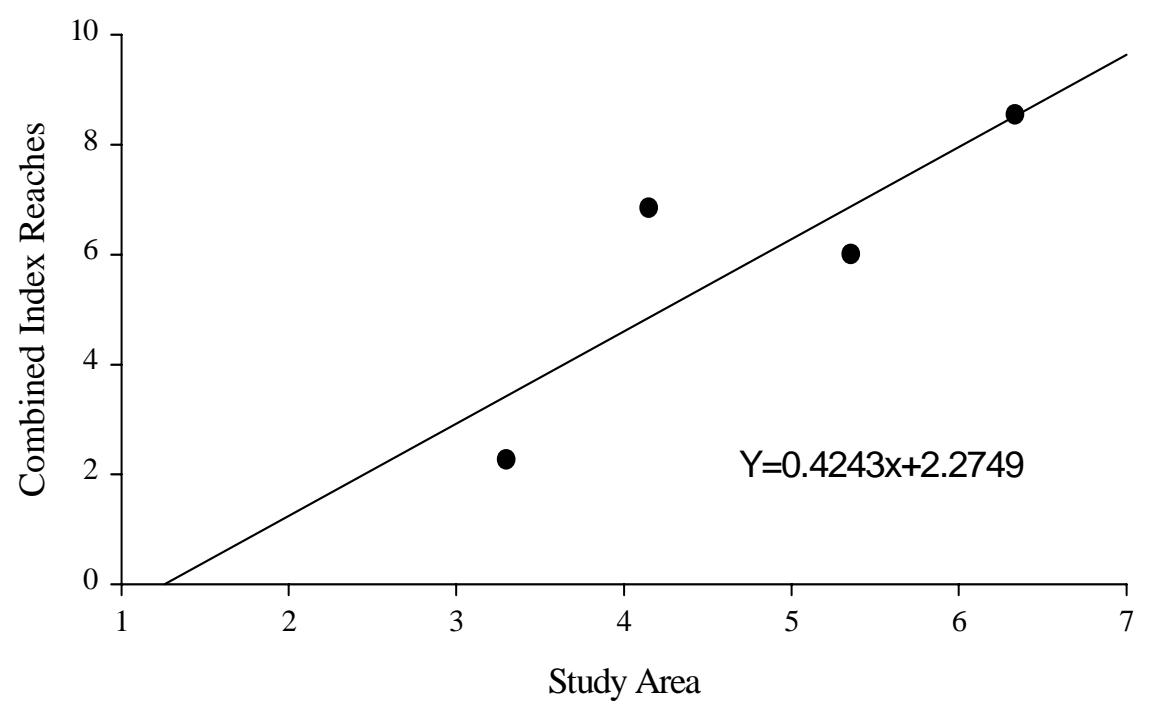

Figure I.9. Regression between density for combined index reach and density study area for juvenile bull trout. 


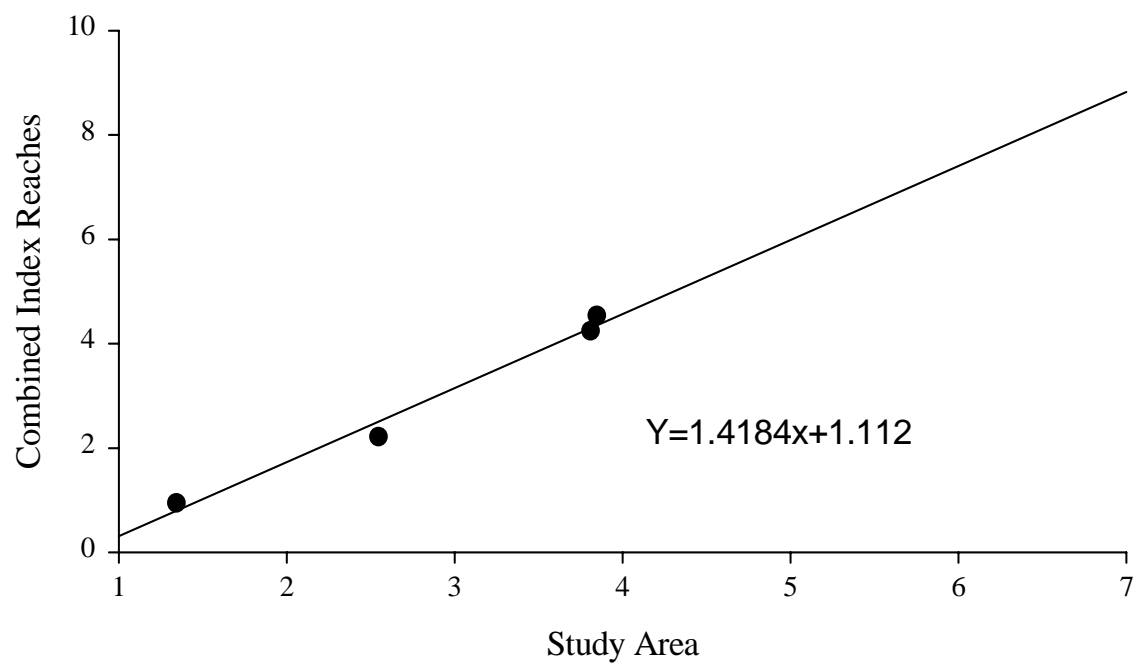

Figure I.10. Regression between density for combined index reach and density study area for brook trout.

\section{Shitike Creek}

The mean relative densities in the combined index reaches for juvenile bull trout and brook trout were $.025 \mathrm{fish} / \mathrm{m}^{2}$ and $.01 \mathrm{fish} / \mathrm{m}^{2}$ during 2002 (Figure I.11).

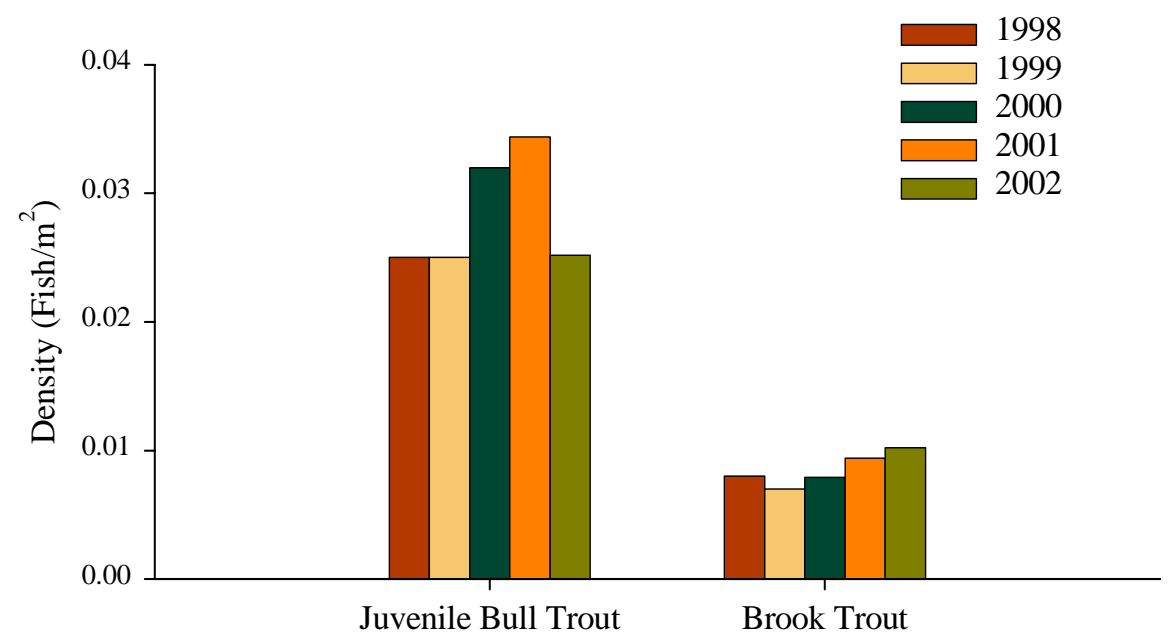

Figure I.11. Mean relative densities of combined index reaches surveyed during 1998-2002 in Shitike Cr.

Juvenile bull trout numbers decreased during 2002 relative to the numbers observed during 1998-1999. Brook trout densities have continued an upward trends since 2000. It should be noted that there has been significant annual fluctuations in relative densities of juvenile bull trout and brook trout among individual index reaches in Shitike Cr. Of the eight index reaches surveyed, seven reaches had decreases in the relative density of 
juvenile bull trout from 2001 observations (Figure I.12). Reach 11 was the only reach to show an increase in relative density. Reach 13 was not surveyed during 2002.

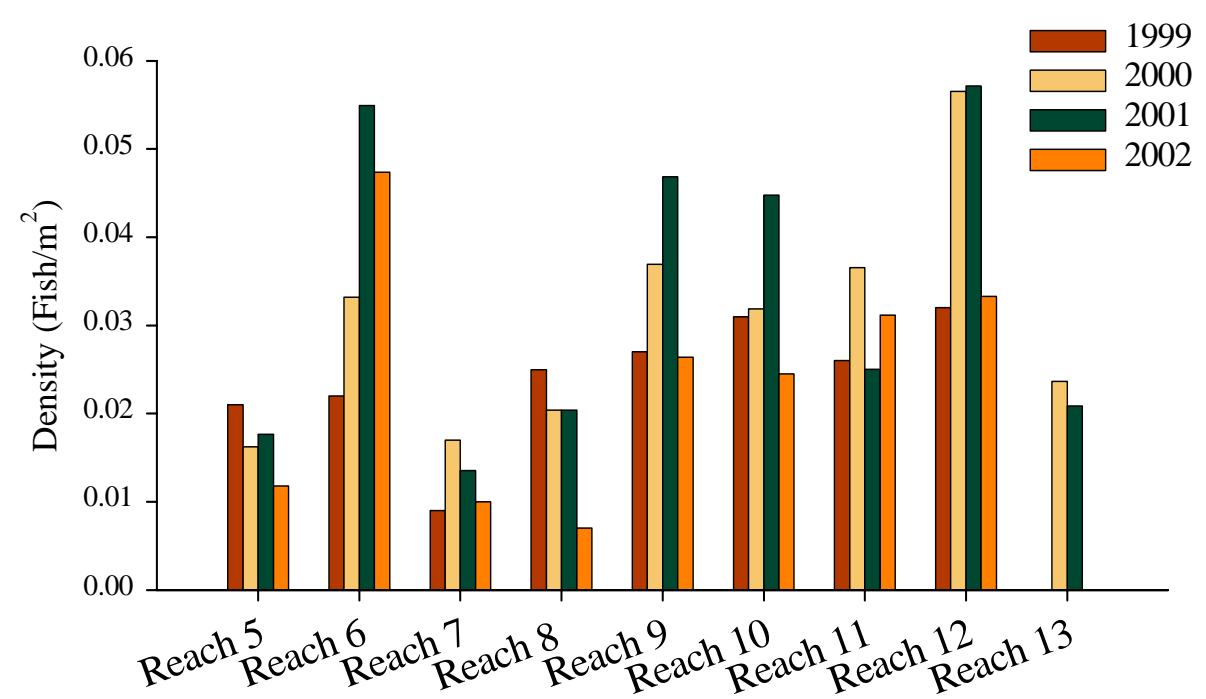

Figure I.12. Relative densities of juvenile bull trout within each index reach surveyed during 1999-2002.

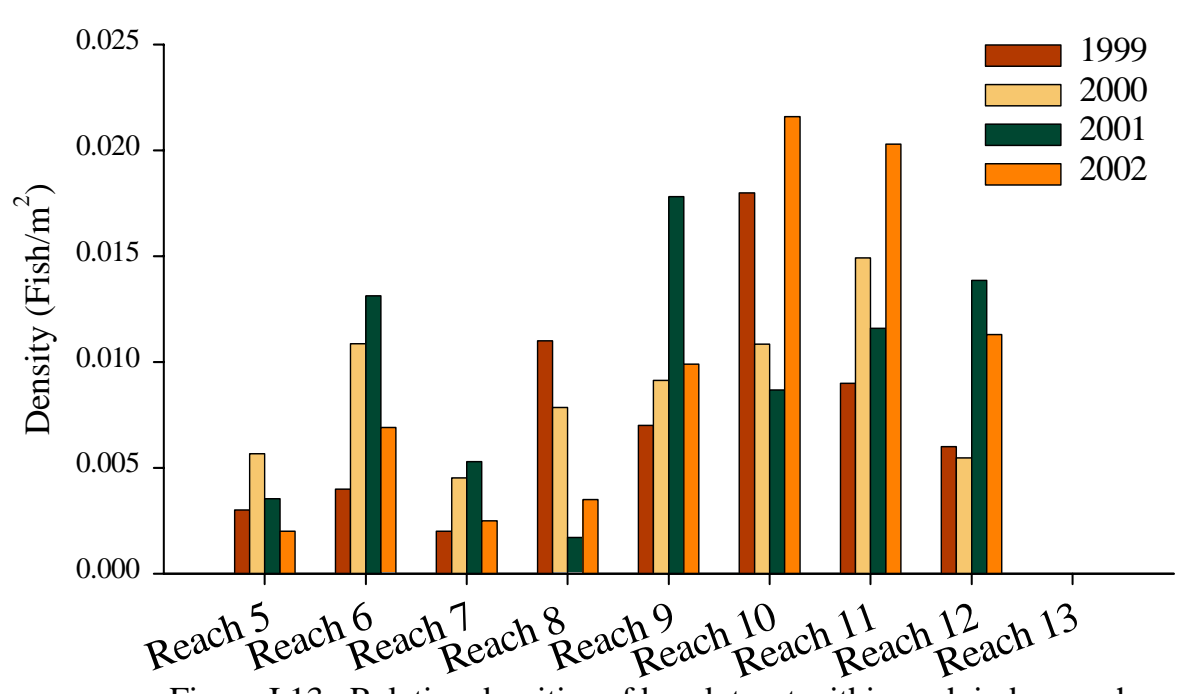

Figure I.13. Relative densities of brook trout within each index reach surveyed during 1999-2002.

Brook trout relative density during 2002 in the combined index reaches increased slightly from 2001 observations. Reaches 8,10 and 11 saw increases in brook trout relative densities whereas in reaches 5, 6, 7,9 and 12 had decreases in the relative densities (Figure I.13). Reaches 10 and 11 saw significant increases in the relative density. Again reach 13 was not surveyed, but in previous years brook trout were absent from this reach. 


\section{Section II \\ Bull Trout Spawning Surveys}

\section{Introduction}

Bull trout require cold water, complex instream habitat and clean gravels for successful spawning. They spawn during the fall when the availability of cool water is limited in most streams. As a result, there is only a small amount of suitable spawning habitat available in most streams (Fraley and Shepard 1989). Identification and protection of spawning areas is crucial for preservation of this species.

Annual redd counts within index reaches are widely used to monitor trends in bull trout abundance throughout their range (Sanborn et al. 1998). Prior to establishing index reaches, basin-wide spawning surveys should be conducted to locate bull trout spawning areas. The surveys, repeated throughout the spawning period, are necessary to determine the specific locations, timing and duration of spawning. Information obtained from basin-wide surveys may be used to determine if a sub-sample of the known spawning habitat, i.e. index reaches, may be used to reliably monitor spawning abundance within a particular stream.

Annual redd surveys began in the Warm Springs River and Shitike Creek during 1998 (Brun 1999). Redd surveys began in Whitewater River in 1995 after a radio tagged bull trout was tracked into the river from Lake Billy Chinook (Thiesfeld et al. 1996). Although Whitewater River is located within the Metolius basin, it is the only tributary of the Metolius River located entirely on the Warm Springs Reservation that supports significant bull trout spawning and juvenile rearing. We conducted redd surveys in this stream to assist with Metolius basin bull trout monitoring.

The objectives of the bull trout redd surveys were to:

1.) Enumerate redds in Warm Springs R., Shitike Cr. and Whitewater R. to establish baseline trend data.

2.) Determine if there are annual changes in spawning distribution within the Warm Springs R. and Shitike Cr.

3.) Detect changes in timing and duration of spawning.

4.) Record water temperatures associated with spawning.

\section{Methods}

Multiple-pass spawning ground surveys were conducted in the Warm Springs R. and Shitike Cr. from August through October 2002. Stream reaches that contained suitable bull trout spawning habitat were surveyed. Suitable spawning habitat was present in portions of streams containing cold water temperatures during the fall $\left(<12^{\circ} \mathrm{C}\right)$, low stream gradient $(<3 \%)$, gravel/cobble substrate and abundant cover including large woody debris, log jams, pools and undercut banks (Buchanan and Gregory 1997; Fraley and Shepard 1989; Reiser and Bjornn 1979). The entire know spawning habitat was 
surveyed in the Warm Springs R. and three in Shitike Cr. The location of the survey reaches was based primarily on access considerations. The locations of the surveys are displayed in Appendix C.

Redd surveys were conducted on alternate weeks from late-August through October in Warm Springs R. and Shitike Cr. during the 1998-2002 spawning seasons. The specific timing of each survey varied within the two-week periods among years due to scheduling difficulties. Suitable spawning habitat in each stream was surveyed 3-5 times from lateAugust through October. One or two surveyors began at the upstream end of each survey reach and walked downstream in or along side the river channel recording redds. Water temperatures were recorded at the beginning and end of each survey reach. Flagging was placed next to each bull trout redd to avoid double counting during later passes. The presence of live adults and their approximate total lengths $(\mathrm{cm})$ were recorded. Redds were tallied on each survey and summed for each reach within the Warm Springs R. and Shitike Cr. after the final pass for each year to obtain the total count.

Whitewater River was surveyed in mid-October 2002. Poor water visibility resulting from glacial turbidity throughout most of the spawning period allowed for only one pass.

\section{Results and Discussion}

\section{Redd Enumeration and Distribution}

A total of one hundred and thirteen redds were observed within the two reaches of the Warm Springs R. Two hundred and four redds were found in the three reaches of Shitike $\mathrm{Cr}$ (Table II.1). Only one pass was conducted in Whitewater R. and no redds were observed.

Table II.1. Bull trout redd survey reaches and numbers of redds recorded in Warm Springs River, Shitike Cr. and Whitewater R. during 2002.

\begin{tabular}{|c|c|c|c|c|c|c|c|c|}
\hline Stream & $\begin{array}{c}\text { Reach } \\
\#\end{array}$ & $\begin{array}{c}\text { Reach } \\
\text { (River } \\
\text { Km) }\end{array}$ & $\begin{array}{c}\text { Reach } \\
\text { Length } \\
\text { (Km) }\end{array}$ & $\begin{array}{c}\text { Total } \\
\text { \# of } \\
\text { Redds }\end{array}$ & $\begin{array}{c}\# \text { of } \\
\text { Redds } \\
\text { Pass1 }\end{array}$ & $\begin{array}{c}\text { \# of } \\
\text { Redds } \\
\text { Pass } 2\end{array}$ & $\begin{array}{c}\text { \# of } \\
\text { Redds } \\
\text { Pass } 3\end{array}$ & $\begin{array}{c}\# \text { of } \\
\text { Redds } \\
\text { Pass } 4\end{array}$ \\
\hline $\begin{array}{c}\text { Warm Springs } \\
\text { R. }\end{array}$ & $\mathrm{I}$ & $57.5-52.0$ & 5.5 & 89 & 5 & 53 & 24 & 7 \\
\hline “" & II & $59.3-57.5$ & 1.8 & 24 & 0 & 1 & 13 & 10 \\
\hline Shitike Cr. & $\mathrm{I}$ & $35.8-31.6$ & 4.2 & 20 & 1 & 5 & 6 & 8 \\
\hline " & II & $41.9-38.6$ & 3.3 & 93 & 2 & 32 & 48 & 11 \\
\hline “" & III & $43.8-41.9$ & 1.9 & 91 & 1 & 26 & 55 & 9 \\
\hline Whitewater R. & I & $20.6-15.8$ & 4.8 & 0 & 0 & - & - & - \\
\hline
\end{tabular}

The redds enumerated in the Warm Springs R. during 2002 was the highest recorded to date (Figure II.1). The redd density (redds/km) during 2002 was 14.75 redds $/ \mathrm{km}$ whereas in 1998-2002 average density was 12.89 redds/km (Figure II.2). Redd densities increased significantly in reach I (Rkm 57.5 - 52.0) during 2002. The redd density in reach I was $16.2 \mathrm{redds} / \mathrm{km}$ during 2002 compared to the 5 -year average density of $12.58 \mathrm{redds} / \mathrm{km}$. In 
reach II the redd density during 2002 was 13.3 redds/km which is similar to the 5 -year average of 13.2 redds $/ \mathrm{km}$ (Table II.2).

Table II.2 Bull trout redd densities (redds/km) in the Warm Spring River,1998-2002.

\begin{tabular}{|c|c|c|c|c|c|c|}
\hline Survey Reach & $\mathbf{1 9 9 8}$ & $\mathbf{1 9 9 9}$ & $\mathbf{2 0 0 0}$ & $\mathbf{2 0 0 1}$ & $\mathbf{2 0 0 2}$ & Mean \\
\hline Reach I (Rkm 52.0-57.5) & 12.7 & 12.2 & 13.6 & 8.2 & 16.2 & 12.58 \\
\hline Reach II (Rkm 57.5-59.3) & 17.2 & 12.2 & 15 & 8.3 & 13.3 & 13.2 \\
\hline Mean & 14.95 & 12.2 & 14.3 & 8.25 & 14.75 & 12.89 \\
\hline
\end{tabular}

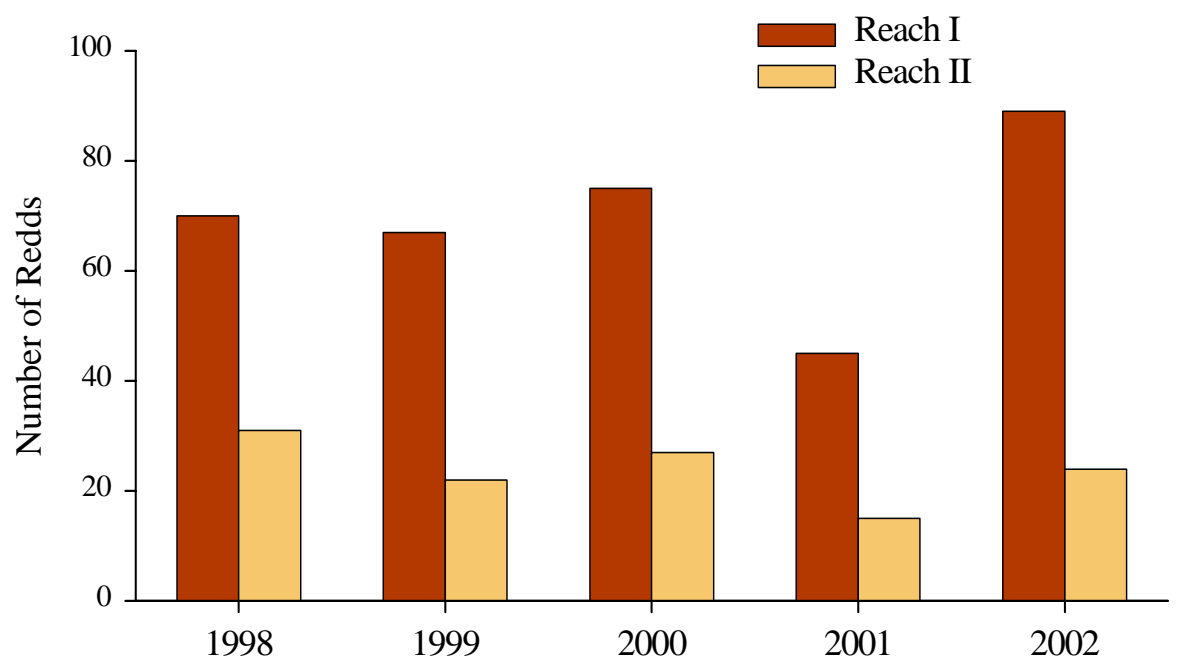

Figure II.1. Total number of redds in the Warm Springs R., 1998-2002.

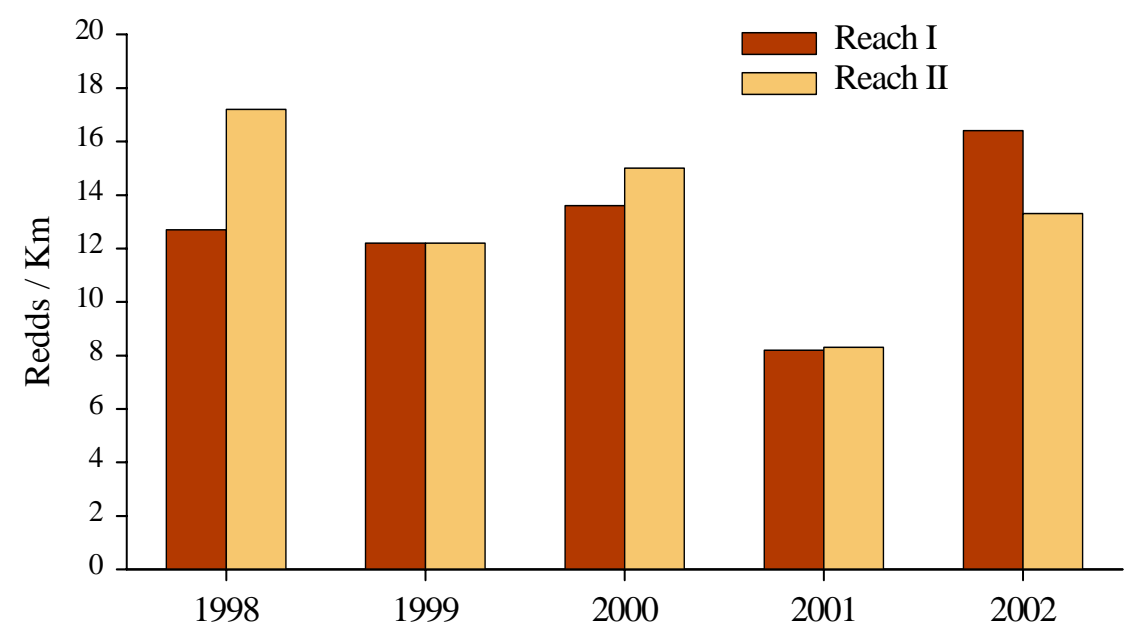

Figure II.2. Redds per kilometer by survey reach (Rkm) in the Warm Springs R., 1998-2002.

A total of two-hundred and four redds were enumerated in Shitike Cr. during 2002. This was the highest count to date and more than double the 2000-2001 counts (Figure II.3). Redd densities rose in all three surveyed reaches within Shitike Cr. during 2002. The 
density was 26.92 redds/km during 2002 compared to the 1998-2002 average of 15.13 redds/km (Figure II.4). The largest increase in redd density was observed in reach III which increased from a 5-year average of $22.3 \mathrm{redds} / \mathrm{km}$ to $47.9 \mathrm{redd} / \mathrm{km}$ in 2002 (Table II.3).

Table II.3. Bull trout redd densities (redds/km) in Shitike Creek, 1998-2002.

\begin{tabular}{|l|l|l|l|l|l|l|}
\hline \multicolumn{1}{|c|}{ Survey Reach } & \multicolumn{1}{|c|}{$\mathbf{1 9 9 8}$} & \multicolumn{1}{|c|}{$\mathbf{1 9 9 9}$} & \multicolumn{1}{|c|}{$\mathbf{2 0 0 0}$} & \multicolumn{1}{|c|}{ (001 } & \multicolumn{1}{c|}{$\mathbf{2 0 0 2}$} & Mean \\
\hline Reach I (Rkm 31.6-35.8) & 6.7 & 4.3 & 1.2 & 2.6 & 4.8 & 3.92 \\
\hline Reach II (Rkm 38.6-41.9) & 17.6 & 17.6 & 15.8 & 16.7 & 28.2 & 19.18 \\
\hline Reach III (Rkm 41.9-43.8) & 12.6 & 20 & 14.7 & 16.3 & 47.9 & 22.3 \\
\hline Mean & 12.3 & 13.97 & 10.57 & 11.87 & 26.97 & 15.13 \\
\hline
\end{tabular}

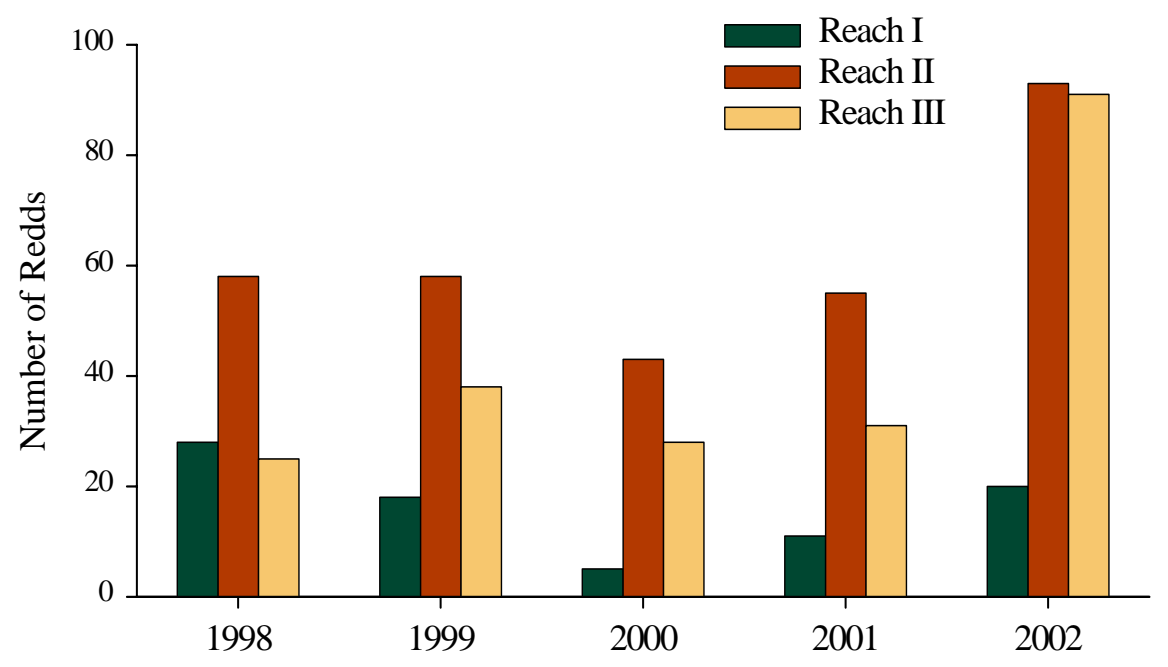

Figure II.3. Total number of redds in Shitike Cr., 1998-2002.

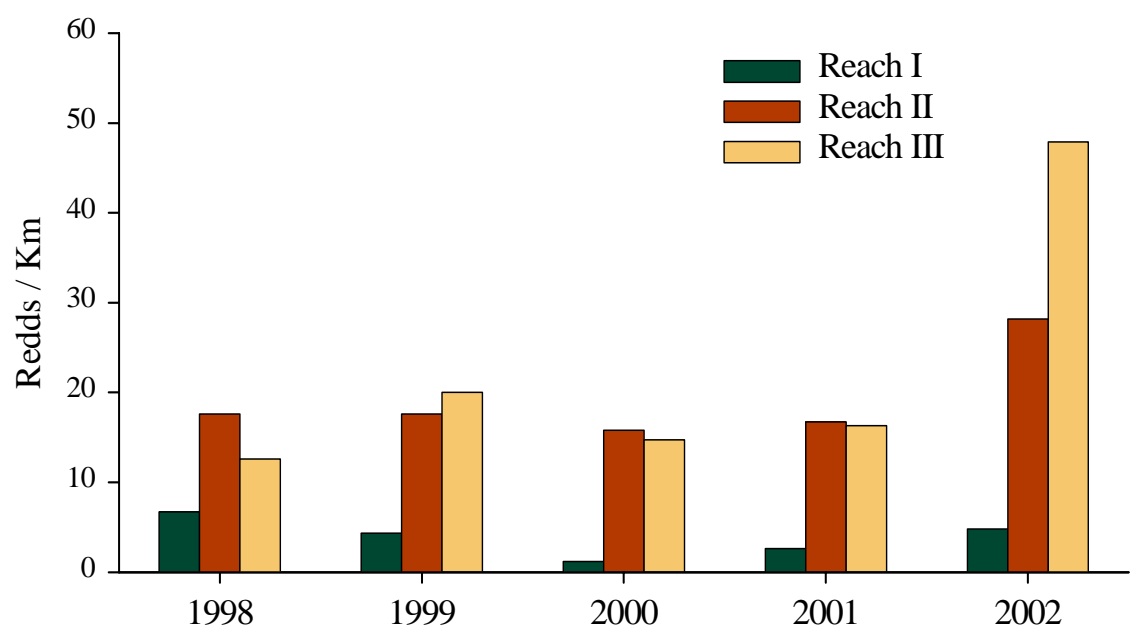

Figure II.4. Redds per kilometer by survey reach (Rkm) in Shitike Cr., 1998-2002. 


\section{Spawning Timing and Associated Water Temperatures}

Bull trout spawning in the Warm Springs R. was first observed during mid-September when the average water temperature declined to $7^{\circ} \mathrm{C}$. This is similar to previous years' observations. Peak spawning also occurred when the water temperature averaged $7^{\circ} \mathrm{C}$ in Warm Springs R. (Figure II.5). Water temperatures ranged from $5.9-7.5^{\circ} \mathrm{C}$ during the September and October bull trout spawning period during 2002.

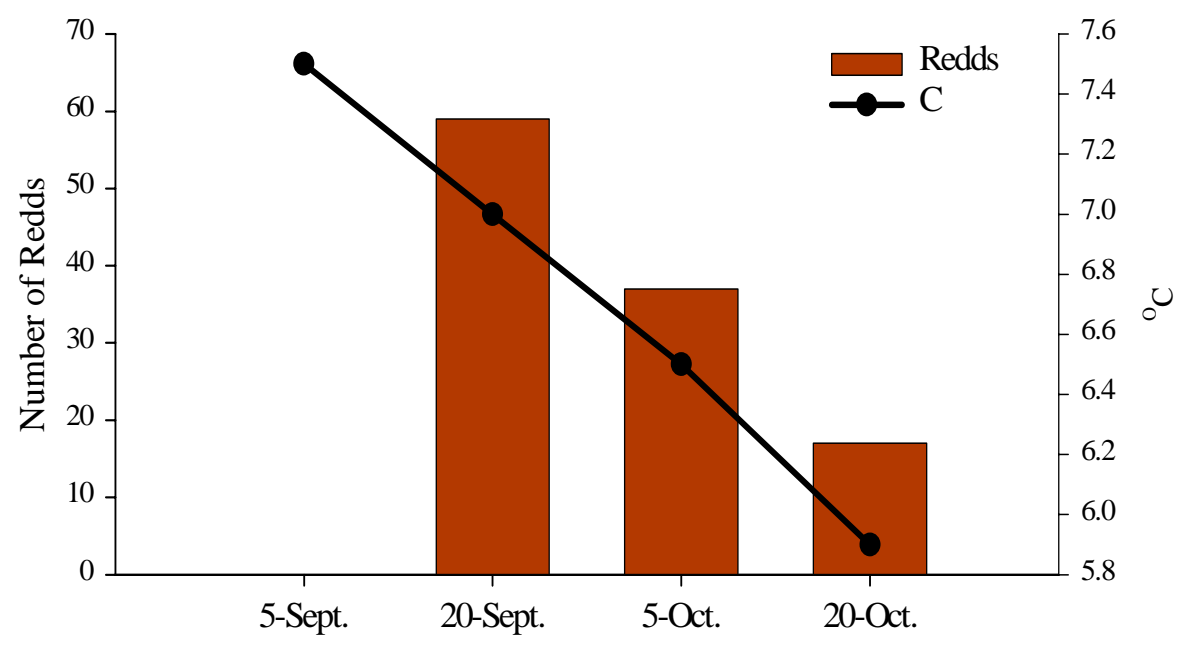

Figure II.5. 2002 Warm Springs R. redd counts and average water temperatures.

Bull trout redds first appeared in Shitike Cr. in late-September when the average water temperature declined to $7.8^{\circ} \mathrm{C}$. This was similar to previous years' observations. Water temperatures in Shitike Cr. ranged from 4.8-7.8 ${ }^{\circ} \mathrm{C}$ during the September and October spawning period. Peak spawning occurred when temperatures declined to $6.3^{\circ} \mathrm{C}$ in Shitike Cr. (Figure II.6). Temperatures during peak spawning in 2002 were $1.5^{\circ} \mathrm{C}$ cooler than in 2001. 


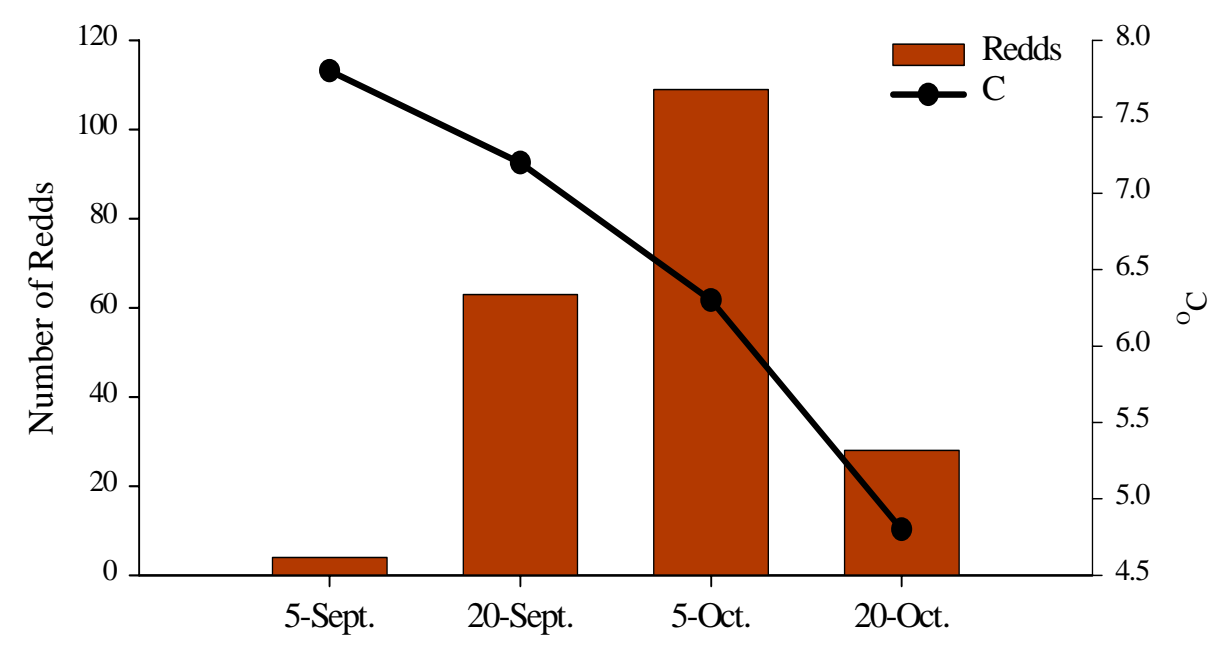

Figure II.6. 2002 Shitike Cr. redds counts and average water temperatures.

\section{Spawning Duration}

We have observed annual shifts in the timing of peak spawning within the Warm Springs R. Peak spawning occurred in mid-September during 1998, 2000 and 2002. During 1999 and 2001, peak spawning occurred during early October (Figure II.7). There appears to be no correlation between peak spawning temperatures and the timing of peak spawning. Water temperatures during the spawning period appear to be consistent during 2000-2002. No water temperature data was recorded during 1998-1999.

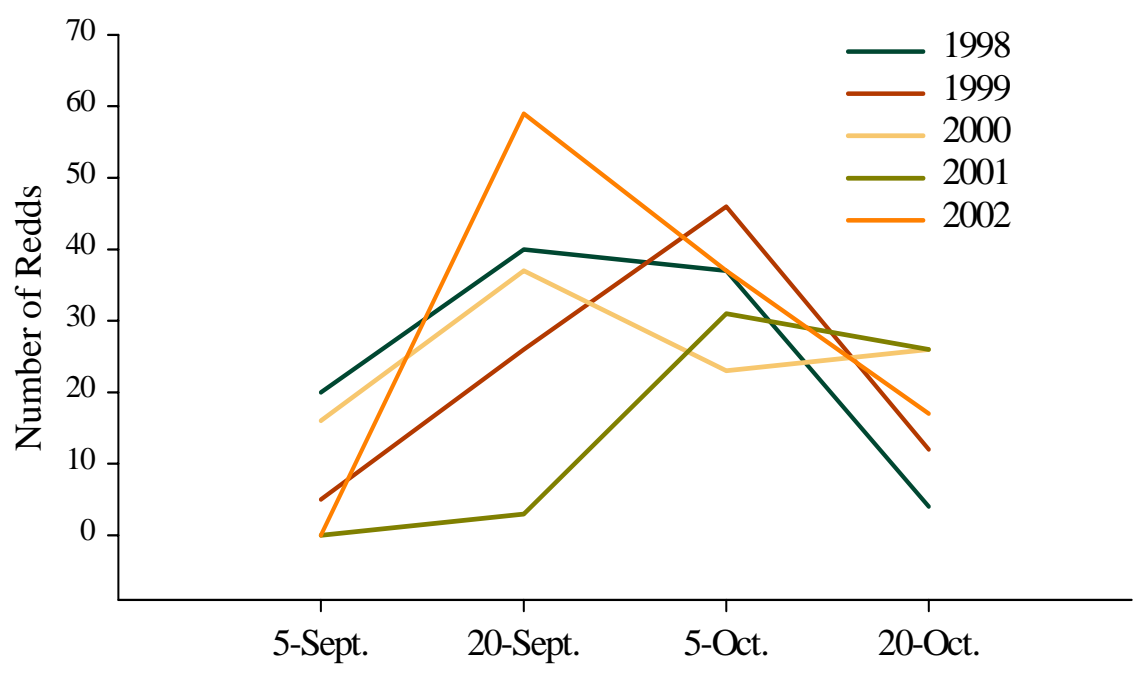

Figure II.7. Peak spawning of bull trout in Warm Springs R., 1998-2002. 
Timing of peak spawning in Shitike Cr. has generally occurred during early October (Figure II.8). The one exception was in 2001 when peak spawning occurred in midSeptember. A possible explanation for 2001 is the low water levels that occurred from lack of mountain snow. The peak spawning temperature during 2001 was $8.0^{\circ} \mathrm{C}$, whereas the $1999-2002$ average was $6.5^{\circ} \mathrm{C}$. The warmer water temperatures during the spawning period in 2001 may have caused the adult bull trout to spawn earlier.

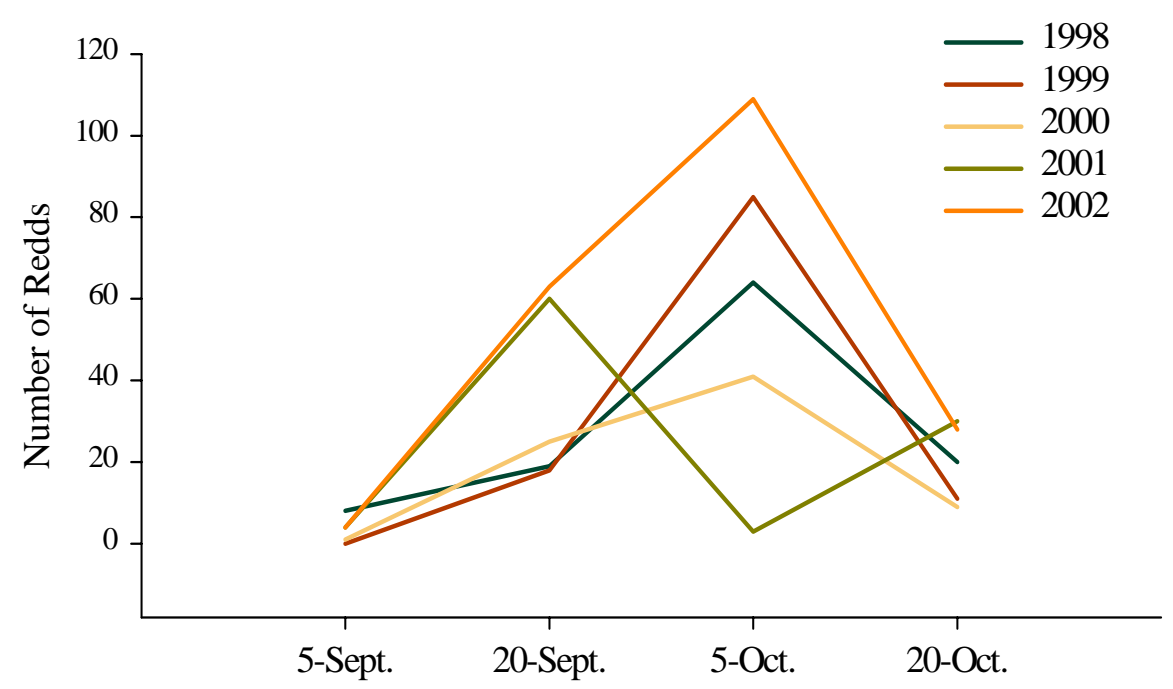

Figure III.8. Peak spawning of bull trout in Shitike Cr., 1998-2002.

\section{Section III \\ Juvenile and Adult Bull Trout Migrant Monitoring}

\section{Introduction}

The majority of bull trout in the lower Deschutes basin exhibit a fluvial life history pattern. Adults spawn and rear near the headwaters of the Warm Springs River and Shitike Creek. Juveniles rear for two to three years in these streams before migrating to the Deschutes River. Adults return to their natal streams to spawn beginning at age IV (Brun and Dodson 2000). The migration timing of juvenile and adult bull trout in the lower Deschutes basin has been monitored since 1995 to determine juvenile emigration and adult immigration timing and escapement. Juvenile emigrant traps have been operated in Shitike Creek and Warm Springs River since 1995. Adult bull trout immigration has been monitored in the Warm Springs River (Rkm 16) at a weir located at Warm Springs National Fish Hatchery (WSNFH) since 1995. A weir equipped with an underwater videocamera was placed downstream of the bull trout spawning grounds in the Warm Springs River (Rkm 52.0) during 2002. Adult immigration monitoring began in Shitike Creek during 2000 with the installation of a fish weir near the creek's mouth (Rkm 1.4). 


\section{Methods}

Juvenile Migration

Juvenile emigration from Shitike Cr. was monitored using a rotary screw trap near the mouth (Rkm 1.4). The trap was operated from mid-March through August and midOctober through mid-December, 24 hours/day, Monday through Friday. All captured bull trout were placed in a solution of $60 \mathrm{mg} / \mathrm{l} \mathrm{MS}-222$ and fork lengths recorded. Juvenile bull trout were clipped either on top or bottom caudal and released approximately one mile upstream of the trap. Trap efficiency and population estimates for both spring and fall bull trout emigration were estimated. To determine weekly trap efficiency, the number of marked and unmarked bull trout released was divided by the number of marked bull trout recaptured. The weekly estimates were summed and divided by the number of releases to determine the population estimate. In determining a population estimate, the fraction of days sampled (T) was multiplied by trap efficiency (X). This number was then divided by the total number of bull trout captured (C) to derive a population estimate $\left(\mathrm{n}^{\wedge}=\mathrm{X}^{*} \mathrm{~T} / \mathrm{C}\right)$. River flows and water/air temperatures were recorded on a daily basis.

In the Warm Springs River a humphrey trap has been operated at Rkm 1.5 in past years. During 2002, the humphrey trap was replaced with an eight-foot rotary screw trap and placed upstream (Rkm 1.75) from the original site. The trap was operated from midMarch through mid-June and late September through mid-December, 24 hours/day, Monday through Friday.

\section{Adult Migration}

\section{Shitike Creek}

A vertical picket fence weir was installed across Shitike Creek near the mouth (Rkm 1.4) during early March 2002. Two fish boxes with fyke entrances were attached to the weir to capture upstream and downstream migrating adults. The weir was checked twice per day, during the morning and late afternoon. All immigrating bull trout captured were tagged with an individually numbered floy tag. The fork length was measured and scale samples were collected. River flows were monitored daily and water temperatures were continuously recorded with a thermograph. Weir operation ceased during early August.

\section{Warm Springs River}

Adult immigration into the Warm Springs River at the WSNFH was monitored by U. S. Fish and Wildlife Service personnel from April through September 2002. Adults were enumerated, inspected for tags and fork lengths estimated using video equipment as they ascended a fish ladder around a concrete weir. 
The number of redds observed and the number of adult bull trout recorded at the WSNFH weir appear to have no correlation (Brun and Dodson 2001). In order to observe the actual number of bull trout entering the spawning grounds, a vertical picket fence weir was located in the meadows (Rkm 52.0) of the Warm Springs R. during mid-June. Monitoring was done through an underwater videocamera, attached to a time-lapse VCR. Due to the remoteness of the location, all equipment was solar powered. Every 72 hours, the videotape was replaced, batteries and electronic equipment checked and the weir was cleaned of all debris. All videotapes were observed and all adult bull trout recorded. Adult fish were identified, upstream/downstream noted and date/time recorded. Water temperatures were continuously recorded with a thermograph. The weir and camera were operated from mid-June through early October.

\section{Results and Discussion}

\section{$\underline{\text { Juvenile Migration }}$}

\section{Shitike Creek}

A total of 74 juvenile bull trout were captured as they emigrated from Shitike Cr. during 2002. The mean fork length was $147.5 \mathrm{~mm}(\mathrm{Sd} .=30.9,95 \% \mathrm{CI}= \pm 7.42)$. Ninety-two percent $(\mathrm{N}=68)$ left Shitike Cr. during the spring period (March - August). The remaining $8 \%(\mathrm{~N}=8)$ were captured during the fall period (October - December). The mean fork length of bull trout during the spring migration was $146.4 \mathrm{~mm}(\mathrm{Sd} .=32.1$, $95 \% \mathrm{CI}= \pm 8.14)$. The mean fork length of fall outmigrants was $158 \mathrm{~mm}(\mathrm{Sd} .=15.1$, $95 \% \mathrm{CI}= \pm 14.0$ ) [Figure III.1].

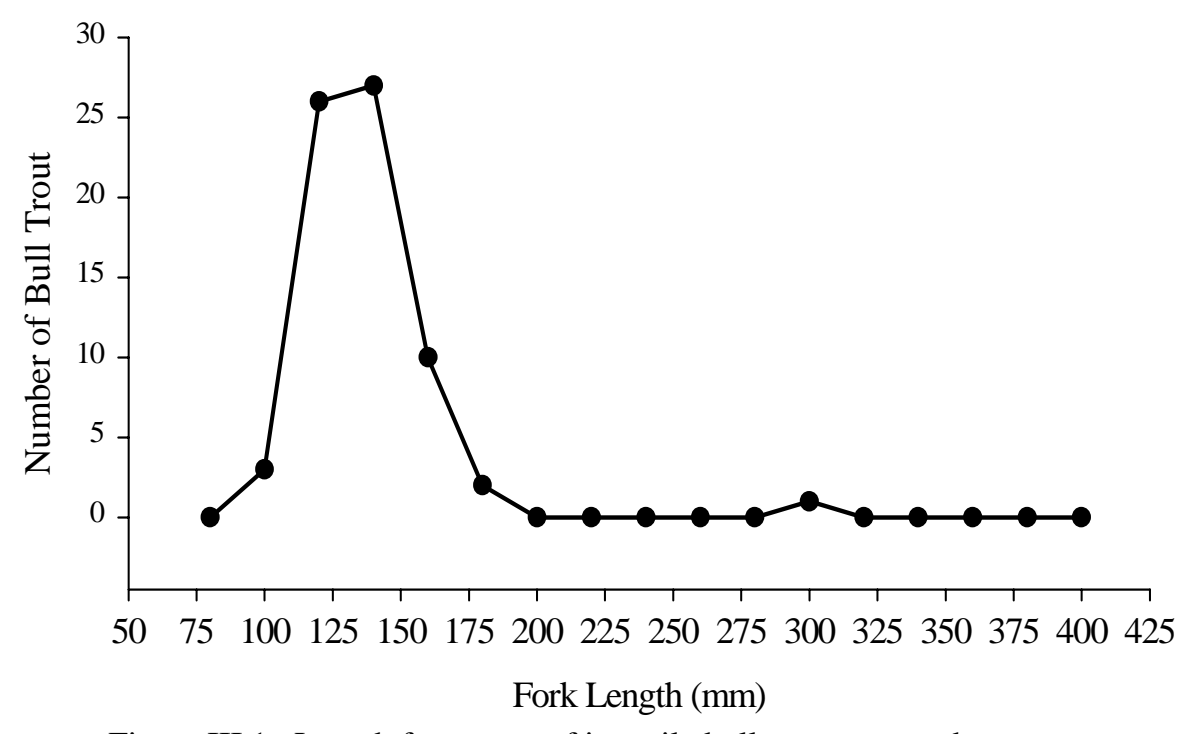

Figure III.1. Length frequency of juvenile bull trout captured at rotary screw trap on Shitike Cr. during 2002.

Age II fish (121-166 mm) accounted for 70\% of the combined spring and fall emigration. Age III fish (167-296 mm) represented 14\% of the catch. The remaining fish were either 
age I (50-120 mm) [8\%] and age IV $(297-431 \mathrm{~mm})$ [1\%]. Five fish $(7 \%)$ were tallied and no lengths recorded.

The majority of juvenile bull trout left Shitike Cr. when temperatures were below $10^{\circ} \mathrm{C}$ (Figure III.2). Water temperatures during the spring migration never exceeded $15^{\circ} \mathrm{C}$. Water temperatures were not recorded during the fall emigration period.

Due to a high water event during mid-April, trap operation ceased for a period of 2 weeks. Trap operation resumed when water flows and velocity decreased. During this period, it is possible that a large number of juvenile bull trout and other juvenile fish were flushed out of Shitike Cr.

During 2002, spring juvenile bull trout trap efficiency and population estimate was generated. The trap efficiency was $42 \%$. The population estimate for spring emigration was 312 fish $(\mathrm{Sd} .=160,95 \% \mathrm{CI}=820,-197)$. Trap efficiency and population estimate for fall emigration was not determined due to the small sample size $(\mathrm{N}=8)$.

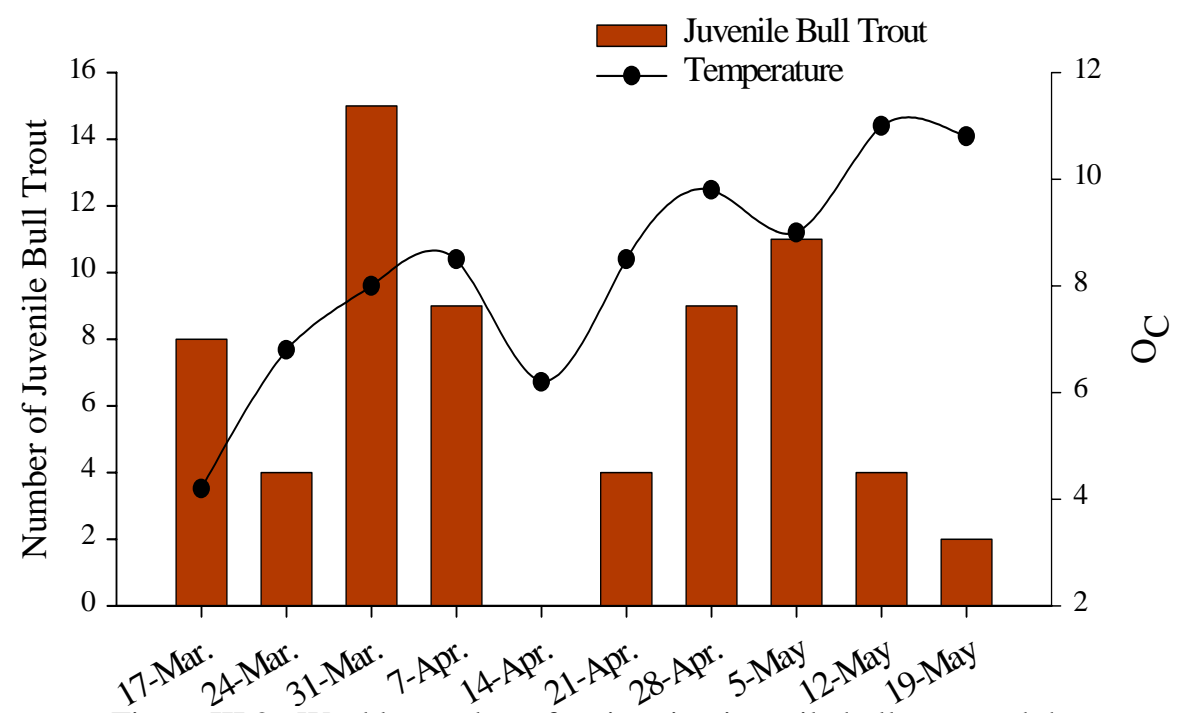

Figure III.2. Weekly number of emigrating juvenile bull trout and the associated 7-day average water temperatures during spring migration, 2002.

\section{Warm Springs River}

No juvenile bull trout were captured in the screw trap in the Warm Springs R. during 2002. As in previous years with the humphrey trap, it is likely the location of the trap prevents effective capture of juveniles in the Warm Springs River. 


\section{$\underline{\text { Adult Immigration }}$}

\section{Shitike Creek}

Only one adult bull trout was captured in the Shitike Cr. weir during 2002. A flood event in April covered the weir with sediment and debris. The weir had to be removed and repaired. The high water event changed the channel morphology at the weir location, which prevented successful operation thereafter. A new location for the weir has been identified and trapping operations will resume during late winter, 2003.

\section{$\underline{\text { Warm Springs River }}$}

A total of thirty adult bull trout were counted as they passed the WSNFH weir during 2002. Since 1995 the number of adult bull trout passing the WSNFH weir has been increasing. The number of adults returning to the Warm Springs R. was the highest number recorded to date (Figure III.3). Immigration occurred from early May through mid-September. The majority of immigration occurred by the end of July. Two fish passed through the weir during August and September. As in 2001, peak migration was observed during the end of May during 2002 (Figure III.4). The mean estimated fork length was $59 \mathrm{~cm}$ (range $30-71 \mathrm{~cm}, \mathrm{Sd} .=10.7,95 \% \mathrm{CI}= \pm 4.07$ ).

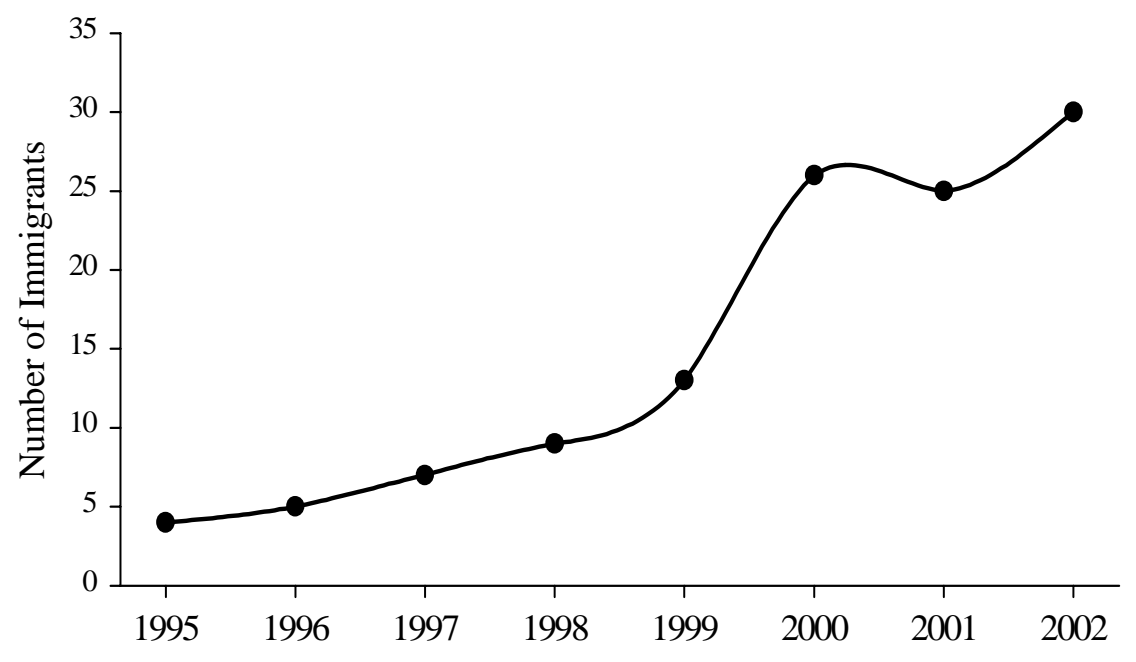

Figure III.3. Number of immigrating adult bull trout counted at the Warm Springs National Fish Hatchery (1995-2002). 


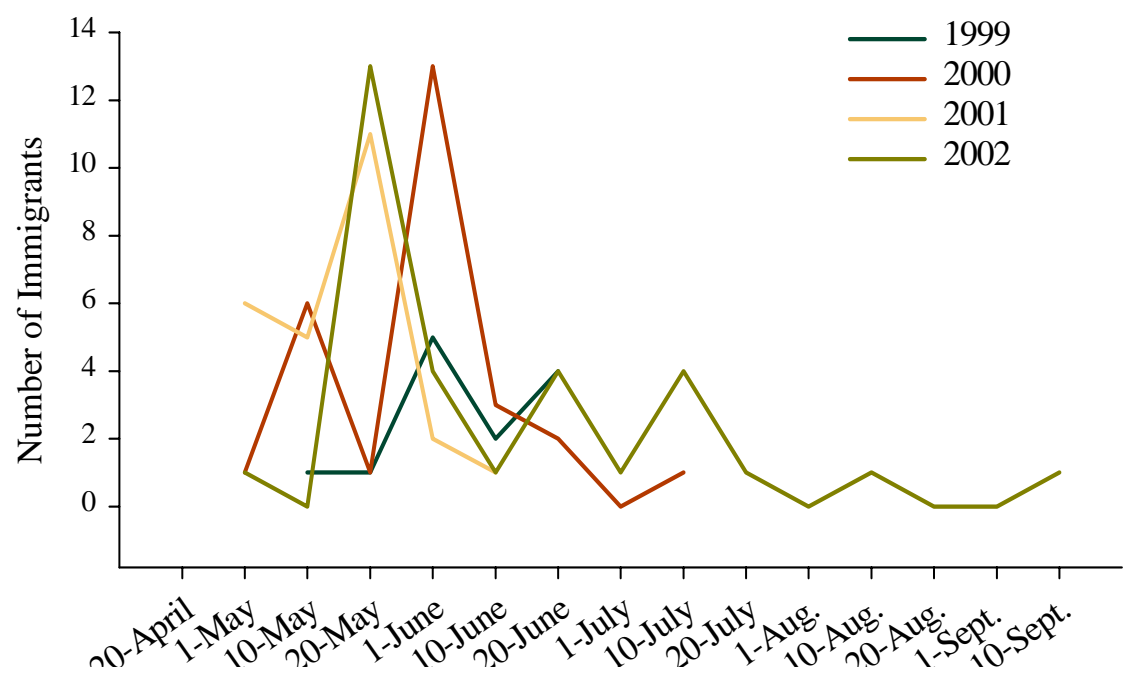

Figure III.4. Emigration timing of adult bull trout at WSNFH, 1999-2002.

Seven day average water temperatures in the Warm Springs R., recorded at WSNFH, ranged from $8.7-19.0^{\circ} \mathrm{C}$ throughout the immigration period. The water temperature averaged $12.9^{\circ} \mathrm{C}$ during the peak of the migration (Figure III.5).

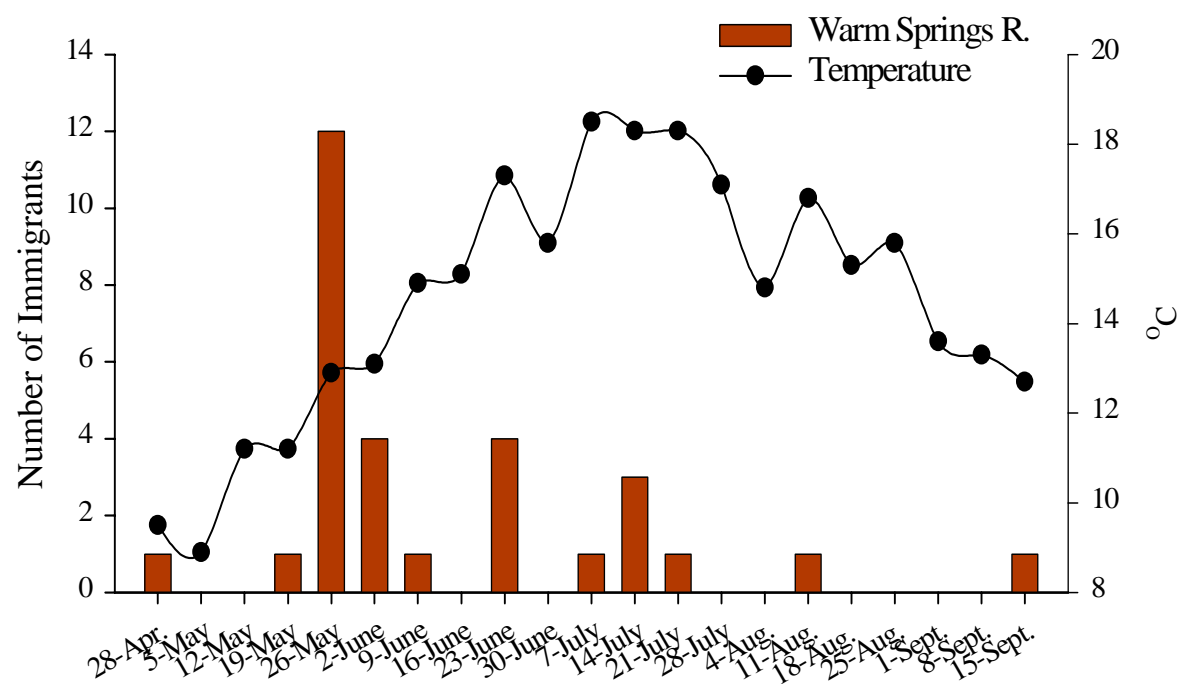

Figure III.5. Water temperatures in the Warm Springs R. at WSNFH during adult bull trout immigration.

Thirty-four adult bull trout passed through the weir near the lower limits of the bull trout spawning grounds in the Warm Springs R during 2002. All fish were recorded using an underwater video camera. The number of immigrants enumerated is likely much lower that the number that actually passed the weir. This was due to our inability to enumerate adults during night time hours. The infrared LED illuminators on the camera did not produce enough light to illuminate the fish box. Modifications to this design were tested during the 2002 field season and will be implemented during 2003. 


\section{Section IV \\ Stream Temperature Monitoring in Warm Springs River and Shitike Creek}

\section{Introduction}

Bull trout require cold water for a significant portion of their lives. Water temperatures have limited bull trout distribution within some drainages (Reiman and McIntyre 1993; Fraley and Shepard 1989; Howell and Buchanan 1992). They require cold water for spawning and juvenile rearing. Juveniles are largely absent in streams with water temperatures exceeding $15^{\circ} \mathrm{C}$. Adults commence spawning when water temperatures decline below $10^{\circ} \mathrm{C}$. However little is known about adult temperature tolerances during migration and pre-spawning holding periods (Buchanan and Gregory 1997; Shepard et al. 1984; Goetz 1989). Tribal, federal and state agencies have promulgated rules designed to protect water temperatures in streams containing bull trout and other salmonids.

However these temperature standards have not been evaluated as to their effectiveness for protecting bull trout in the lower Deschutes River. Our objective is to conduct long term water temperature monitoring in Shitike Creek and Warm Springs River to determine the annual range of water temperatures associated with tributary entry; migration and holding; and spawning. Temperature monitoring began during 1999 and is ongoing. The results will be used to evaluate the effectiveness of using water temperature standards to protect bull trout habitat and to further refine bull trout temperature requirements by lifehistory stages.

\section{Methods}

A total of 16 calibrated, continuously recording thermographs (Onset Computer Corporation, Stow Away ${ }^{\mathrm{TM}}$ and HoboTemps ${ }^{\mathrm{TM}}$ ) were located throughout Shitike Cr. and Warm Springs R. to record stream temperatures from spring through the late fall. Thermographs were placed near the river mouths' to record hourly temperatures associated with immigration into each stream; within the migratory/holding corridors; and within the spawning grounds (Table IV.1 \& IV. 2) [Brun 1999, Brun and Dodson 2000]. Thermographs were deployed during March and April, prior to bull trout immigration and retrieved during late-October and November 2002, after the cessation of spawning. The data was summarized using Eel River Water Temperature Analysis Program V. 97.8 .

For analysis the data from individual thermographs were grouped by life history use i.e. migration, pre-spawning holding, and spawning/rearing areas within each stream. The data was averaged to obtain a single daily maximum and 7-day average maximum temperature $\left({ }^{\circ} \mathrm{C}\right)$ for each stratum during the time period that adult bull trout occupied each area. The dates from which water temperature data was used in the analysis for each stratum is displayed in Table IV.3. 
Table IV.1. Location and duration of temperature data loggers in Shitike Cr. during 2002.

\begin{tabular}{|c|c|c|c|c|}
\hline & Location & Rkm & Deployment Date & Recovery Date \\
\hline Immigration & Weir & 1.4 & 19-March & 10-Oct. \\
\hline Holding & Bennets & 14.0 & 19-March & 22-Oct. \\
\hline & Powerline & 23.0 & 8-May & 19-Sept. \\
\hline Spawning/Rearing & Peters Pasture & 38.1 & 25-April & 4-Nov. \\
\hline & Upper & 43.5 & 7-June & 8-Oct. \\
\hline
\end{tabular}

Table IV.2. Location and duration of temperature data loggers in Warm Springs R. during 2002.

\begin{tabular}{|c|c|c|c|c|}
\hline & Location & Rkm & Deployment Date & Recovery Date \\
\hline Immigration & Mouth & .4 & 19-March & 9-Oct. \\
\hline & Hatchery & 14.0 & 19-March & 25-Oct. \\
\hline Holding & Powerline & 41.8 & 19-March & 25-Oct. \\
\hline Spawning/Rearing & Hehe-Schoolie & 55.5 & 19-March & 22-Oct. \\
\hline & W240 Bridge & 68.1 & 22-April & 24-Oct. \\
\hline
\end{tabular}

Table IV.3. The time periods used for water temperature data analysis for immigration, holding and spawning/rearing in Shitike Cr. and Warm Springs R. during 2002.

\begin{tabular}{|c|c|c|}
\hline & Shitike Cr. & Warm Springs R. \\
\hline Immigration & 1 May to 15 July & 1 May to 1 September \\
\hline Holding & 1 May to 1 September & 1 May to 1 September \\
\hline Spawning/Rearing & 1 September to 31 October & 1 September to 31 October \\
\hline
\end{tabular}

\section{Results}

$\underline{\text { Shitike Cr. }}$

Figure IV.1. displays the water temperatures recorded in Shitike Cr. during adult immigration through spawning during 2002. The mean water temperature recorded during bull trout immigration into Shitike $\mathrm{Cr}$. was $14.3^{\circ} \mathrm{C}$ (range $10.9-18.2^{\circ} \mathrm{C}$ ). Within the mid-portion of Shitike Cr. (Rkm 14.0-17.7), used by adults for holding during June through August, the mean water temperature was $12.8^{\circ} \mathrm{C}$ (range 8.3-16.3 ${ }^{\circ} \mathrm{C}$ ). The mean water temperature recorded in the spawning grounds $(\mathrm{Rkm} 30-45)$ was $6.7^{\circ} \mathrm{C}$ (range 2.1 $9.0^{\circ} \mathrm{C}$ ) during the September through October spawning period.

Seven-day average of the daily maximum (7 DADM) mean water temperatures in Shitike Cr. during 2002 were cooler than in 2000-2001 but warmer than 1999 observations (Figure IV.2). Near the mouth of Shitike Cr. the 7 DADM mean water temperatures during immigration were 1.0-3.8 ${ }^{\circ} \mathrm{C}$ lower than recorded during 2000-2001. Average water temperatures within the holding areas during the adult staging period were $0.1-1.8^{\circ}$ $\mathrm{C}$ lower than during 2000-2001. In the spawning grounds, average water temperatures remained relatively similar to previous years' observations. The 7 DADM water temperature fluctuations during immigration, holding and spawning/rearing within Shitike Cr. are displayed in Table V.4 during 1999-2002. 


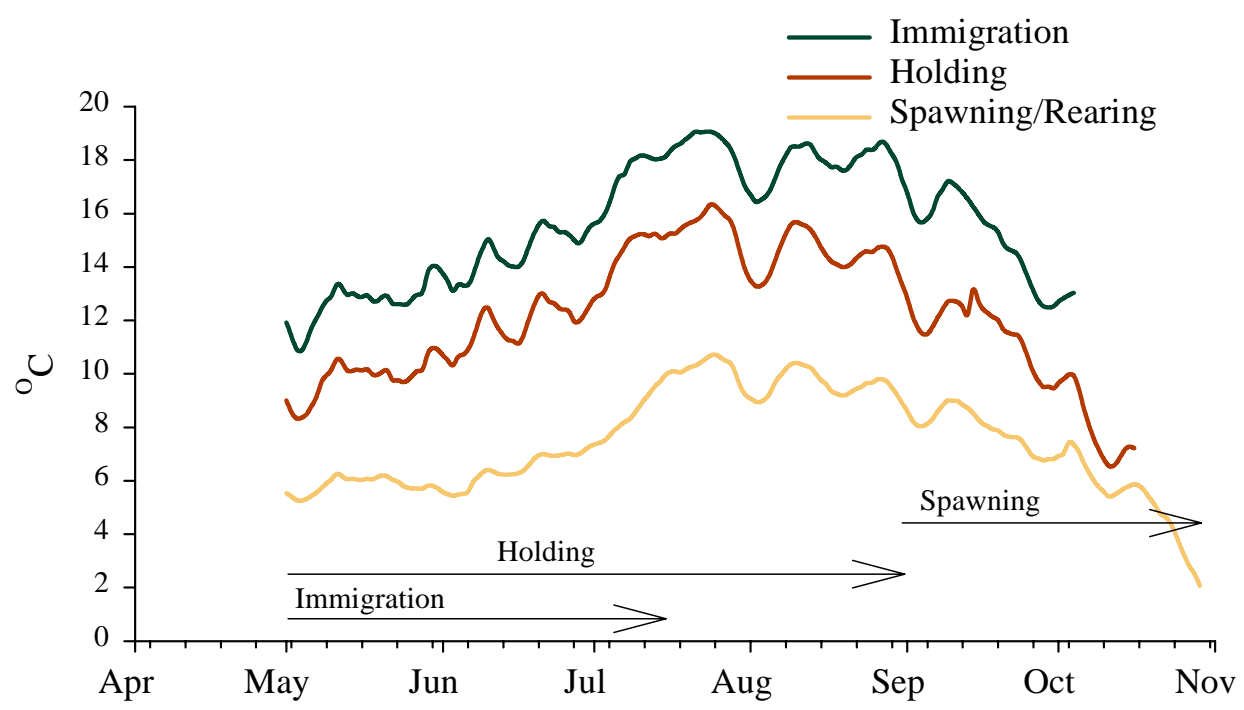

Figure IV.1. 7 DADM (7-Day Average of Daily Maximum) water temperatures during 2002 in Shitike Cr. The arrows represent the time period adult bull trout were immigrating, holding or spawning.

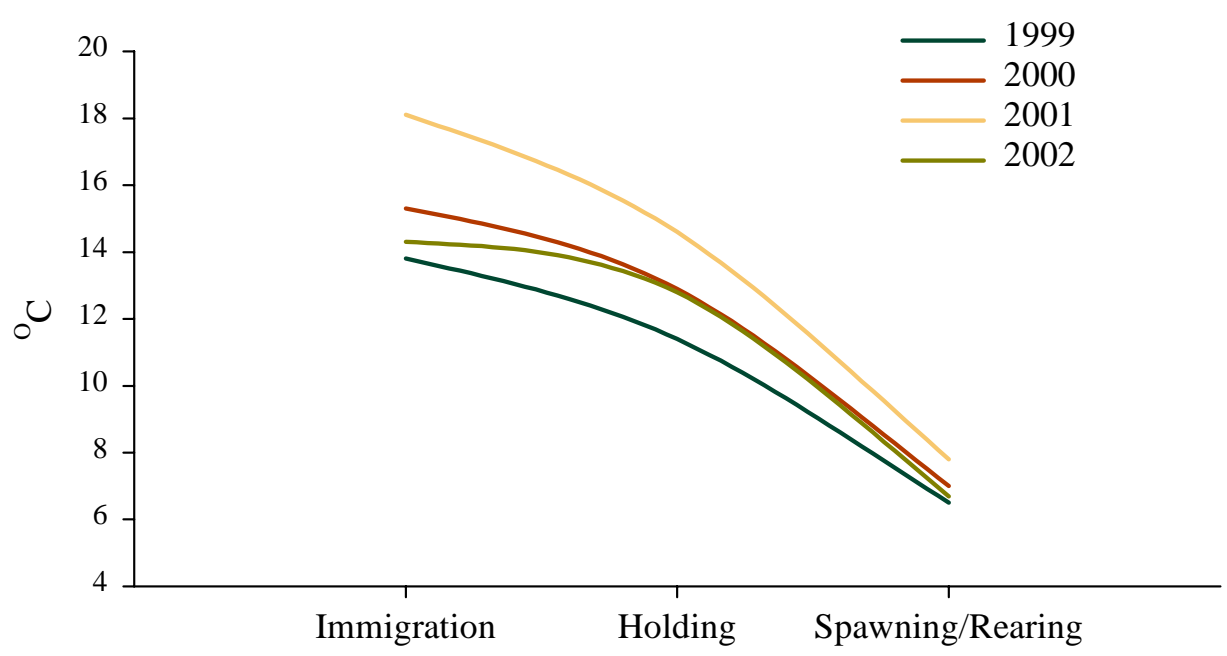

Figure IV.2. 7 DADM mean water temperatures in Shitike Cr. when adult bull trout entered the stream through spawning during 1999-2002. 
Table V.4. 7 DADM water temperatures in Shitike Cr. during seasonal immigration, holding and spawning/rearing (May-November), 1999-2002.

\begin{tabular}{|r|c|c|c|}
\hline & Migration & Holding & Spawning \\
\hline 1999 & 13.8 & 11.4 & 6.5 \\
\hline Mean & 10.5 & 7.8 & 4.6 \\
\hline Max & 17.4 & 18.5 & 7.8 \\
\hline Std. Dev. & 1.93 & 2.55 & 1.06 \\
\hline Variance & 3.74 & 6.51 & 1.13 \\
\hline Mean & 15.3 & 12.9 & 7.0 \\
\hline Min. & 11.9 & 7.8 & 5.3 \\
\hline Max & 19.4 & 16.9 & 9.2 \\
\hline Std. Dev. & 2.10 & 2.52 & 1.21 \\
\hline Variance & 4.43 & 6.33 & 1.47 \\
\hline Mean & 18.1 & 14.6 & 7.8 \\
\hline Min. & 13.1 & 9.1 & 5.5 \\
\hline Max & 23.7 & 18.5 & 9.8 \\
\hline Std. Dev. & 2.81 & 2.55 & 1.33 \\
\hline Variance & 7.92 & 6.51 & 1.78 \\
\hline Mean & 14.3 & 12.8 & 6.7 \\
\hline Min. & 10.9 & 8.3 & 2.1 \\
\hline Max & 18.2 & 16.3 & 9.0 \\
\hline Std. Dev. & 1.91 & 2.25 & 7.75 \\
\hline Variance & 3.67 & 5.07 & 3.06 \\
\hline
\end{tabular}

\section{Warm Springs R.}

Water temperatures near the mouth (Rkm 0.4) and WSNFH ( $\mathrm{Rkm} \mathrm{16.0)}$ average $17.6^{\circ} \mathrm{C}$ (range 10.5-22. $0^{\circ} \mathrm{C}$ ) during adult bull trout immigration (May 1 - September 1) [Figure V.3]. The average water temperatures in the Warm Springs R. canyon (Rkm 16.0 - 52.0) during the May to September holding period was $13.4^{\circ} \mathrm{C}$ (range 8.6-16.4 ${ }^{\circ} \mathrm{C}$ ). During the spawning period the average temperature was $7.3^{\circ} \mathrm{C}$ (range 6.4-8.0 $0^{\circ} \mathrm{C}$ ) between $\mathrm{Rkm}$ $52-63$.

Unlike Shitike Cr., water temperatures in the Warm Springs R. have remained relatively consistent during holding and spawning, 1999-2002 study period. The 7-day average of the daily maximum (7 DADM) mean water temperatures during immigration has had the highest variation since 1999 (Figure V.4). Temperatures in the spawning grounds have been similar since 2000. The Warm Springs R. is a spring-fed system as such one would expect water temperatures to be more consistent over the years than a snow-melt system, such as Shitike Cr. 


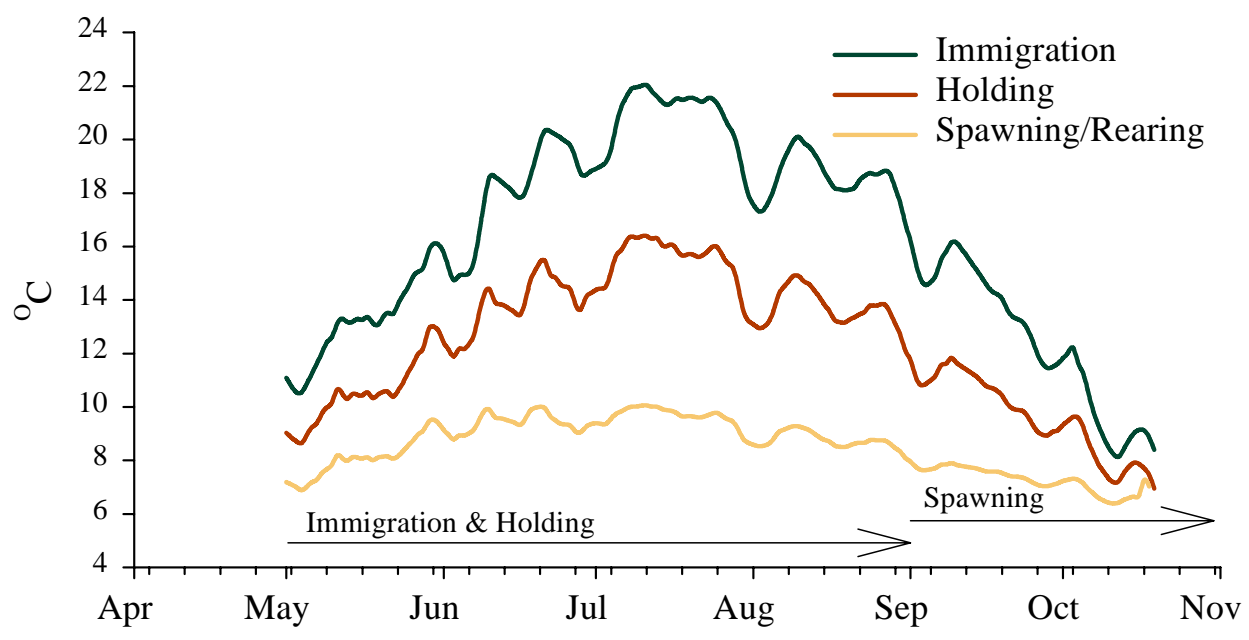

Figure IV.3. 7 DADM (7-Day Average of Daily Maximum) water temperatures during 2002 in Warm Springs R. The arrows represent the time period adult bull trout were immigrating, holding or spawning.

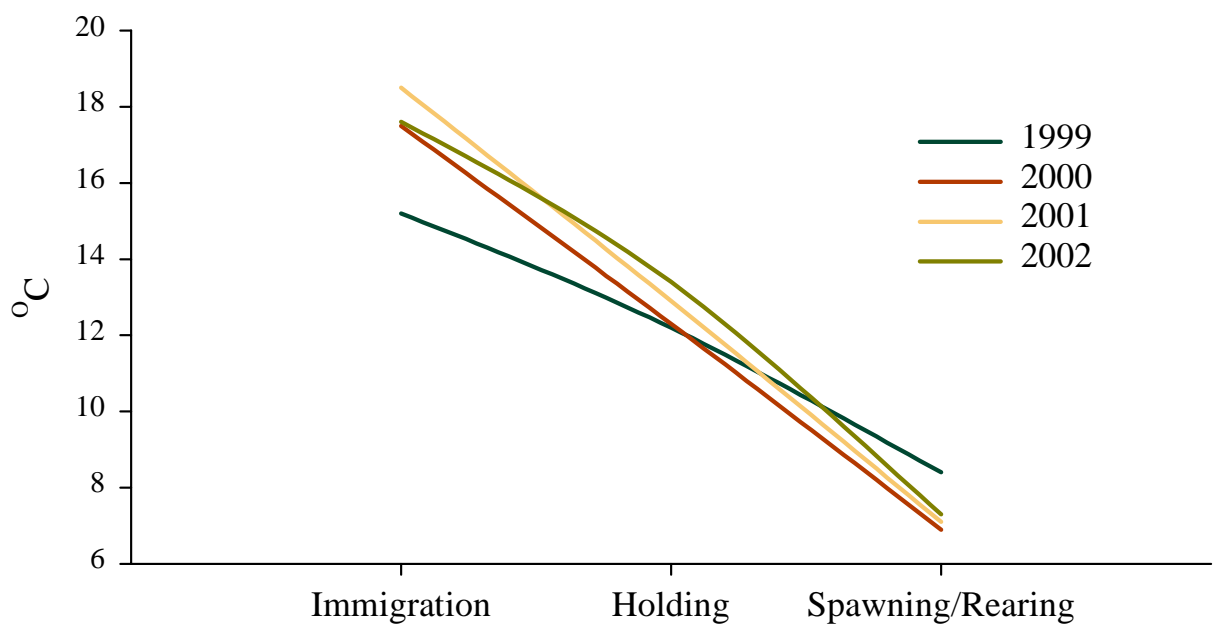

Figure IV.4. 7 DADM mean water temperatures in Warm Springs R. when adult bull trout entered the stream through spawning during 1999-2002.

The 7 DADM water temperature fluctuations during immigration, holding and spawning/rearing time periods within Warm Springs R. during 1999-2002 are displayed in Table IV.5. 
Table IV.5. 7 DADM water temperatures in the Warm Springs R. during season immigration, holding and spawning/rearing (May-November), 1999-2002.

\begin{tabular}{|r|c|c|c|}
\hline & Migration & Holding & Spawning \\
\hline 1999 & 15.2 & 12.2 & 8.4 \\
\hline Mean. & 9.2 & 8.4 & 6.7 \\
\hline Max & 19.4 & 15.0 & 9.4 \\
\hline Std. Dev. & 2.91 & 1.86 & 0.82 \\
\hline Variance & 8.44 & 3.46 & 0.67 \\
\hline Mean & 17.5 & 12.3 & 6.9 \\
\hline Min. & 11.0 & 8.3 & 6.1 \\
\hline Max & 20.9 & 14.2 & 7.5 \\
\hline Std. Dev. & 2.32 & 1.61 & 0.41 \\
\hline Variance & 5.39 & 2.59 & 0.17 \\
\hline Mean & 18.5 & 12.9 & 7.1 \\
\hline Min. & 12.4 & 10.6 & 6.1 \\
\hline Max & 21.8 & 14.9 & 8.3 \\
\hline Std. Dev. & 2.16 & 1.07 & 0.78 \\
\hline Variance & 4.66 & 1.14 & 0.61 \\
\hline Mean & 17.6 & 13.4 & 7.3 \\
\hline Min. & 10.5 & 8.6 & 6.4 \\
\hline Max & 22.0 & 16.4 & 8.0 \\
\hline Std. Dev. & 3.14 & 2.06 & 0.46 \\
\hline Variance & 9.84 & 4.22 & 0.21 \\
\hline
\end{tabular}




\section{References}

Brun, C.V. 1999. Bull trout distribution and abundance in the waters on and bordering the Warm Springs Reservation, 1998 Annual Report. Bonneville Power Administration, Portland, Oregon.

Brun, C.V. 2000. Bull trout distribution and abundance in the waters on and bordering the Warm Springs Reservation, 1999 Annual Report. Bonneville Power Adminstration, Portland, Oregon.

Brun, C.V. and R.D. Dodson. 2001. Bull trout distribution and abundance in the waters on and bordering the Warm Springs Reservation, 2000 Annual Report. Bonneville Power Administration, Portland, Oregon.

Buchanan, D.V. and S.V. Gregory. 1997. Development of water temperature standards to protect and restore habitat for bull trout and other cold water species in Oregon. Pages 119-126 in Mackay, W.C., M.K. Brewin, and M. Monita, editors. Friends of the bull trout conference proceedings. Bull Trout Task Force (Alberta), c/o Trout Unlimited Canada, Calgary.

Buchanan, D.V., M.L. Hanson and R.M. Hooton. 1997. Status of Oregon's bull troutdistribution, life history, limiting factors, management considerations and status. Oregon Department of Fish and Wildlife, Portland, Oregon.

Dambacher, J.M. and K.K. Jones. 1997. Stream habitat of juvenile bull trout populations in Oregon, and benchmarks for habitat quality. Proceedings of the Friends of the Bull Trout Conference. Calgary, Alberta.

Fraley, J.J. and B.B. Shepard. 1989. Life history, ecology and population status of bull trout (Salvelinus confluentus) in the Flathead Lake and River system, Montana. Northwest Science 63:133-143.

Goetz, F. 1989. Biology of the bull trout, Salvelinus confluentus, a literature review. U.S. Department of Agriculture, Forest Service, Willamette National Forest, Eugene, Oregon.

Goetz, F. 1991. Bull trout life history and habitat study. U.S. Department of Agriculture, Forest Service, Deschutes National Forest, Bend, Oregon.

Howell, P.J. and D.V. Buchanan, editors. 1992. Proceedings of the Gearhart Mountain bull trout workshop. Oregon Chapter of the American Fisheries Society, Corvallis. 
Moore, K.M., K.K. Jones and J.M. Dambacher. 1993. Methods for stream habitat surveys: Oregon Department of Fish and Wildlife, Aquatic Inventories Project. Oregon. Department of Fish and Wildlife, Research and Development Section, Corvallis, Oregon.

Pratt, K.L. 1992. A review of bull trout life history. Pages 5-9 in P.J. Howell and D.V. Buchanan, editors. Proceedings of the Gearhart Mountain Bull Trout workshop. Oregon Chapter of the American Fisheries Society, Corvallis, Oregon.

Ratliff, D.E. 1992. Bull trout investigations in the Metolius River - Lake Billy Chinook system. Pages 37-44 in P.J. Howell and D.V. Buchanan, editors. Proceedings of the Gearhart Mountain Bull Trout workshop. Oregon Chapter of the American Fisheries Society, Corvallis, Oregon.

Ratliff, D.E. and P.J. Howell. 1992. The status of bull trout populations in Oregon. Pages 10-17 in P.J. Howell and D.V. Buchanan, editors. Proceedings of the Gearhart Mountain Bull Trout workshop. Oregon Chapter of the American Fisheries Society, Corvallis, Oregon.

Ratliff, D.E., S.L. Thiesfeld, W.G. Weber, A.M. Stuart, M.D. Riehle and D.V. Buchanan. 1996. Distribution, life history, abundance, harvest, habitat and limiting factors of bull trout in the Metolius River and Lake Billy Chinook, Oregon, 1983-1994. Information Report, Oregon Department of Fish and Wildlife, Portland, Oregon.

Rieman, B.E. and J.D. McIntyre. 1993. Demographic and habitat requirements for conservation of bull trout. General Technical Report INT-302. U.S. Forest Service. Intermountain Research Station, Boise, Idaho.

Reiser, D.W. and T.C. Bjornn. 1979. Habitat requirements of anadromous salmonids. U.S. Forest Service, General Technical Report DNW-96. Pacific Northwest Forest and Range Experiment Station. Portland, Oregon.

Sanborn, B., P. Callahan, G. Decker, C.F. Frissell, G. Watson and T. Weaver. 1998. The relationship between land management activities and habitat requirements of bull trout. Montana Fish, Wildlife and Parks. Helena, Montana.

Shepard, B., K. Pratt and P. Graham. 1984. Life histories of westslope cutthroat and bull trout in the upper Flathead River Basin, Montana. Montana Department of Fish, Wildlife and Parks, Kalispell, Montana.

Thiesfeld, S.L., A.M. Stuart, D.E. Ratliff and B.D. Lampman. 1996. Migration patterns of adult bull trout in the Metolius River and Lake Billy Chinook, Oregon. Oregon Department of Fish and Wildlife Information Report 96-1. Portland, Oregon. 
Thurow, R.F. 1994. Underwater methods for study of salmonids in the Intermountain West. General Technical Report INT-GTR-307. U.S. Forest Service.

Intermountain Research Station. Ogden, Utah.

Thurow, R.F. and D.J. Schill. 1996. Comparison of day snorkeling, night snorkeling and electrofishing to estimate bull trout abundance and size structure in a secondorder Idaho stream. North American Journal of Fisheries Management 16:314323. 
Appendix A. Juvenile bull trout survey locations in the Warm Springs R. and Shitike Cr.

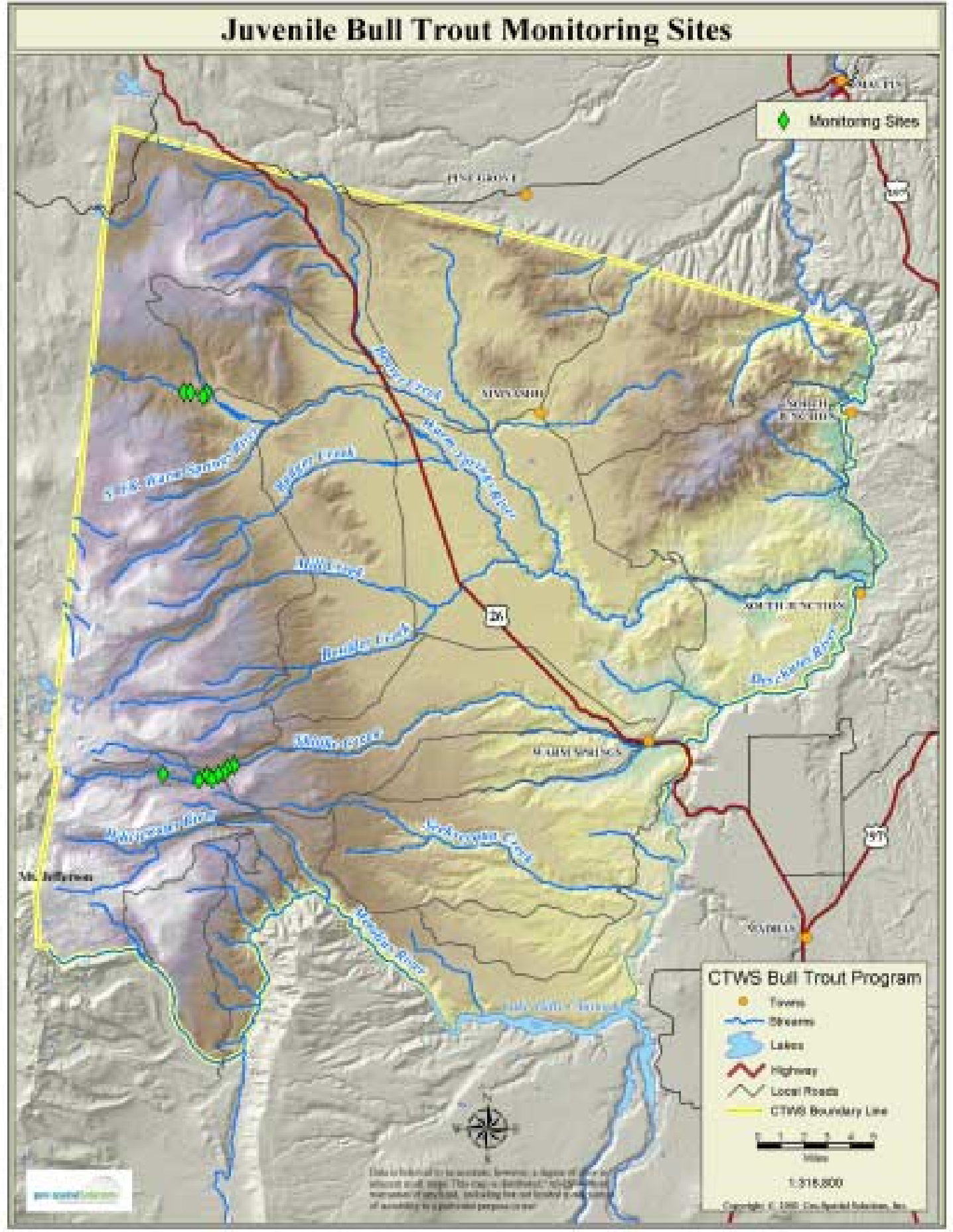


Appendix B. Four index reach and $2.4 \mathrm{~km}$ study area location in the Warm Springs R.

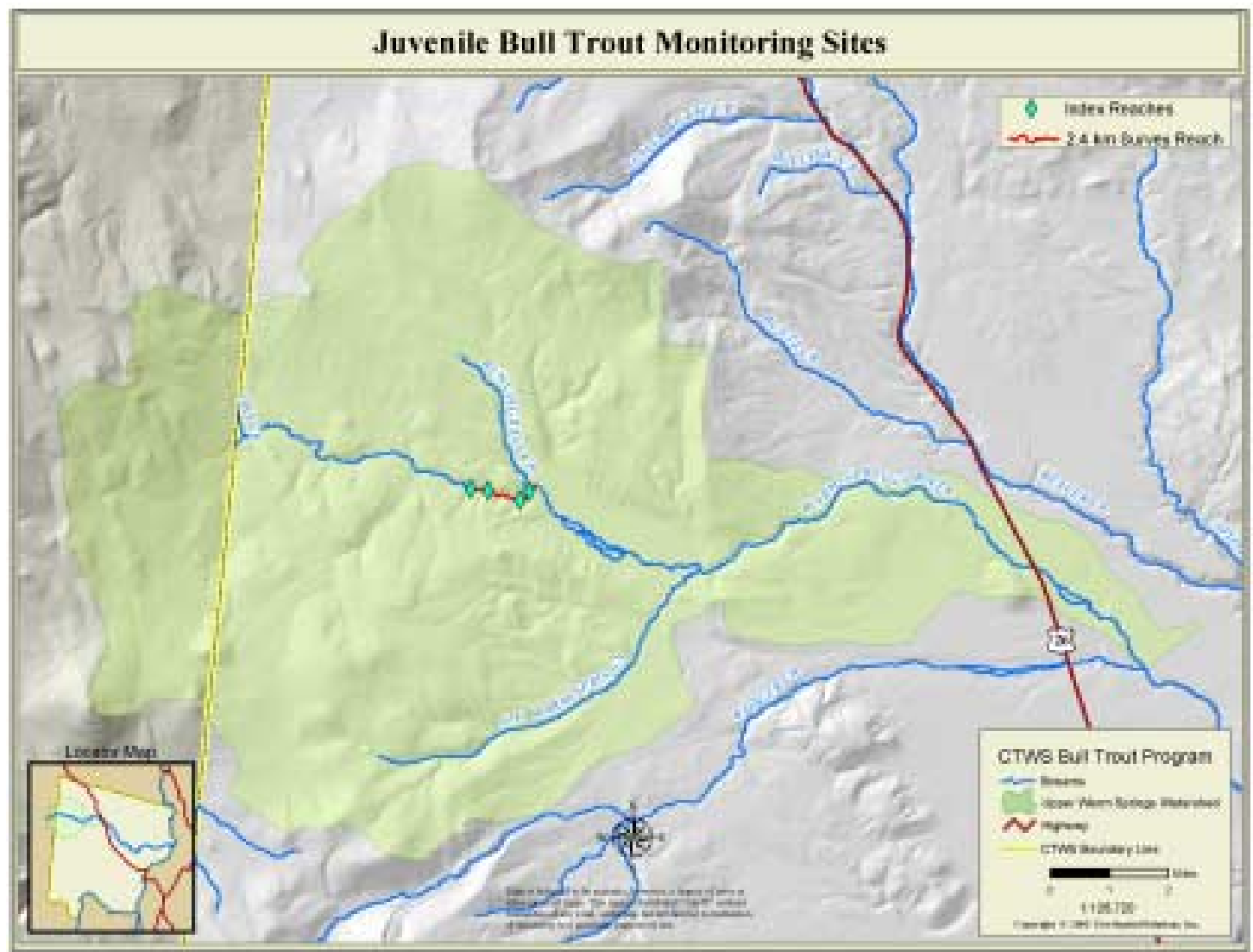


Appendix C. Bull trout spawning survey index reaches.

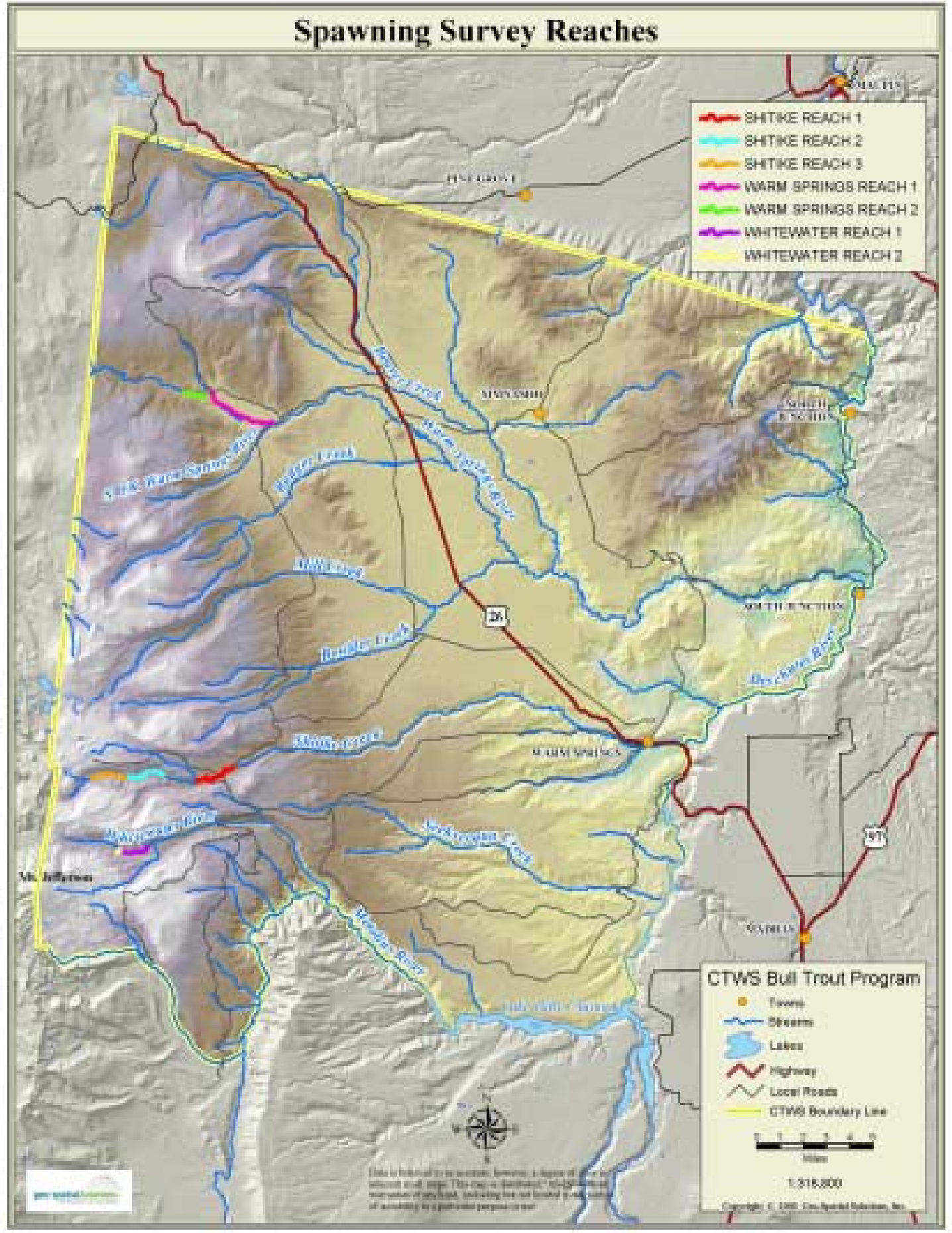

